\title{
The social impacts of dams: A new framework for scholarly analysis
}

\author{
Julian Kirchherr*, Katrina J. Charles \\ School of Geography and the Environment, University of Oxford, South Parks Road, OX1 3QY Oxford, United Kingdom
}

\section{A R T I C L E I N F O}

\section{Article history:}

Received 7 October 2015

Received in revised form 22 February 2016

Accepted 22 February 2016

Available online 8 April 2016

\section{Keywords:}

Large dams

Hydropower

Social impact

Resettlement

Social impact assessment

Framework

\begin{abstract}
A B S T R A C T
No commonly used framework exists in the scholarly study of the social impacts of dams. This hinders comparisons of analyses and thus the accumulation of knowledge. The aim of this paper is to unify scholarly understanding of dams' social impacts via the analysis and aggregation of the various frameworks currently used in the scholarly literature. For this purpose, we have systematically analyzed and aggregated 27 frameworks employed by academics analyzing dams' social impacts (found in a set of 217 articles). A key finding of the analysis is that currently used frameworks are often not specific to dams and thus omit key impacts associated with them. The result of our analysis and aggregation is a new framework for scholarly analysis (which we call 'matrix framework') specifically on dams' social impacts, with space, time and value as its key dimensions as well as infrastructure, community and livelihood as its key components. Building on the scholarly understanding of this topic enables us to conceptualize the inherently complex and multidimensional issues of dams' social impacts in a holistic manner. If commonly employed in academia (and possibly in practice), this framework would enable more transparent assessment and comparison of projects.
\end{abstract}

(C) 2016 Elsevier Inc. All rights reserved.

\section{Introduction}

The conceptualization of social impacts of infrastructure development is inherently complex, with a multitude of social impacts occurring over various time, space and value dimensions. Shields (1974, p. 265) defined social impacts as "responses of social systems to the physical restructuring of their environments", a definition which does not help define these impacts in a way that can be operationalized, though. The attempt by Vanclay (2002) to conceptualize social impacts illustrated the difficulties of operationalization particularly well; the author suggested as many as 80 variables to be considered.

Such a comprehensive list can serve as an initial guide for scholarly analysis, but lacks focus. Hence, further conceptual advance is needed to develop complex social impact issues of infrastructure development into a usable framework. Frameworks may be broadly defined as a prioritized organization of ideas regarding a topic (Slootweg et al., 2001). They explicate "either graphically or in narrative form, the main things to be studied - the key factors, concepts, or variables - and the presumed relationships among them" (Miles and Huberman, 1994, p. 18). Theoretical discourse on frameworks is rare in the scholarly social impact literature, though (Howitt, 2011). Indeed, scholars in this extremely applied field of study oftentimes seem more concerned with the question of how to collect the data than with the question of what

\footnotetext{
* Corresponding author.

E-mail addresses: julian.kirchherr@sant.ox.ac.uk (J. Kirchherr), katrina.charles@ouce.ox.ac.uk (K.J. Charles).
}

data to collect - the latter question frameworks help to answer (Howitt, 2011). As a consequence of this lack of conceptual discourse, Harvey (2011, p. 17) even finds that the "[conceptual social impact] refresh button needs to be pushed".

This paper aims to contribute to the conceptual discourse on social impacts induced by infrastructure development and unify scholarly understanding of the topic at hand. A particular infrastructure, namely dams, is chosen for this contribution. This is motivated by three reasons. First, a global boom in dam construction is currently under way and thus dams demand scholarly attention overall (further discussed in the next paragraph). Second, dams feature numerous peculiarities and thus necessitate a specific framework (further discussed in Section 2). Third, the scholarly literature on dams is extremely scattered and thus particularly requires conceptual discourse on existing frameworks (further discussed in Section 3).

Indeed, dams are back on the infrastructure development agenda. Upon publication of the seminal report by the World Commission on Dams in 2000, the rate of construction of dams reduced as funders such as the World Bank largely opted out of dam construction (Schneider, 2013). However, dams are now an investment hotspot again, particularly those generating electricity. One recent study estimated that at least 3700 hydropower dams ( $>1 \mathrm{MW}$ ) are either planned or already under construction. These are expected to increase global hydropower production by 73\% (Zarfl et al., 2014). 93\% of this production increase will be provided by 847 large dams with a capacity of $>100$ MW each (Zarfl et al., 2014). 39 GW of capacity was added in 2014 alone (IHA, 2015), equivalent to almost three times of Africa's 
current total installed capacity (World Energy Council, 2015). Up to 47\% of the projected USD 57 trillion to be invested in infrastructure by 2030 is expected to be in power and water infrastructure (Dobbs et al., 2013). This increasing rate of dam development is also accelerating the pace of development-induced displacement. No accurate data on the total number of people displaced by infrastructure development is available, however, Scudder (2011) estimates it may be more than 200 million people in the previous century, of which possibly 80 million (40\%) were displaced due to dams. The impacts of these displacements are challenging to address for practitioners such as dam developers or governments. Scholarly reflections on the social impact of dams (reviving the idea of "writing as an intervention" (Jordan et al., 2011)) may help prepare the conceptual grounds for addressing these impacts, we believe.

The remainder of this paper is organized as follows. In Section 2, we expand our argument on why frameworks are important and explain why a particular framework on the social impact of dams is needed. In Section 3, we provide an overview of current key scholarly frameworks on the social impact of dams and critically analyze the most commonly used frameworks. We start Section 3 with a note on methods explaining how the alleged key frameworks were derived from the literature. In Section 4, we describe and explain our suggested framework (called 'matrix framework') which was developed as an aggregation and result of the analyses in Section 3. We also outline how it may improve current frameworks on the social impact of dams as well as likely limitations. Our argument is summarized in Section 5.

\section{Ontheneedfor frameworks overall and a specific framework for dams}

\subsection{The significance of frameworks}

We understand frameworks as a starting point for any research endeavor on the social impact of dams. Frameworks provide a system indicating which components and dimensions of dams' social impact to investigate, but can also exclude some. Accordingly, the results of an analysis are interlinked with and frequently the direct result of the framework employed by the scholar (Rossouw and Malan, 2007). A comprehensive framework may ensure that the scholar comprehensively considers the various impacts of a project upfront before (possibly) focusing on specific impacts. This helps to position the analysis and results. Indeed, Vanclay (2002, p. 189) claims that many scholarly studies lacking frameworks are not of satisfactory standard because these reports "failed to consider the full range of social impacts that might be experienced". General agreement regarding a framework to be used is also central to advance a field of study. Only if scholars employ identical or similar frameworks, studies can be handily compared and aggregated and thus knowledge can accumulate. If every scholar starts his or her analysis conceptually from scratch, this may result in a standstill of the field.

Frameworks are not only essential for scholarly analysis, but also for practitioners. Review committees and the public can only assess impacts objectively across a variety of projects if frameworks are specific and consistent. A lack of framework consistency may eventually lead to a lack of credibility (Harvey, 2011). Social impacts of infrastructure projects are usually assessed by practitioners (e.g. social impact consultants at firms such as Coffey or SMEC) via social impact assessments (SIAs) which are grounded in various frameworks. SIAs may be defined, in the narrowest conceptualization, as "the process of identifying the future consequences of a current or proposed action [e.g. a dam project]" (Becker, 2001, p. 311), ideally helping "to manage the social issues associated with planned interventions" (Vanclay and Esteves, 2011, p. 3). These SIAs are interlinked with scholarly studies on social impact and scholarly frameworks. Indeed, researchers and their conceptual discourse and frameworks on social impacts are acknowledged to contribute to best practice SIA (IAIA, 2016).
While frameworks are designed to be systematic and comprehensive, there are a number of criticisms of them. The (sometimes) narrow focus of frameworks is criticized for blinding those adopting them to any issues falling outside it (Alt and Shepsle, 1990). Furthermore, frameworks are criticized by leading scholars for focusing not on the issues that matter, but only on those that can be easily operationalized (Vanclay, 2004). In addition, a social impact framework may operate "at such high level of generalization that it does not deal adequately with variation" (Scudder, 2006, p. 41).

Admittedly, frameworks are no silver bullet against incomprehensive analyses. Vanclay (2002, p. 200) notes that "the variables [...] important must be locally defined, and there may be local considerations that a generic listing does not adequately represent". We note that this includes both quantitative and qualitative variables (with qualitative variables frequently difficult to operationalize) and agree that these must always be contextualized instead of mechanistically applied when carrying out a scholarly analysis. A high level of generalization, as feared by Scudder (2006), can be circumvented if specific frameworks for specific infrastructure projects are adopted.

\subsection{Theneedfora specificframeworkonthesocialimpactsof dams}

Any framework is generic since it simplifies the issue of study to its (alleged) key components and dimensions. However, the level of genericity can significantly differ from framework to framework (Miles and Huberman, 1994). A universal social impact framework applicable for any infrastructure development is imaginable. However, such a universal framework would be particularly high-level and thus not able to account for peculiarities of specific infrastructures, as pointed out by Juslén (1995) and Scudder (2005, p. 1 ff.) (with the latter author arguing that the WCD policy principles would be superior to those of the World Bank since the WCD principles (unlike the World Bank principles) "apply specifically to large hydro").

We also pledge for a specific framework on the social impact of dams since dams feature at least three peculiarities which may be disregarded in a universal framework on the social impacts of infrastructure:

- Dams frequently serve several primary purposes (e.g. electricity production, flood control or irrigation), making the components of social impact more complex than for other infrastructure projects. WCD (2000) estimates that $1 / 3$ of dams serve two or more primary purposes, with the share of multi-purpose-dams increasing in recent years. Infrastructure such as a coal-fired power plant or gas pipelines only serves a single primary purpose (in these cases: electricity generation or the transporting of gas). A universal framework would likely be able to account for these single primary purposes, but possibly not the myriad primary purposes of dams.

- Dams have an immediate spatial social impact far beyond the construction activities and the associated displacement, the key spatial impact areas of most infrastructure projects. Dams' social impact reach upstream populations, e.g. via restrictions on water use in order to fill the reservoir (Duflo and Pande, 2007), downstream, e.g. via benefits from irrigation water and flood protection (with Richter et al. (2010) estimating that 472 million people downstream have been impacted by dam construction); and nationally, e.g. via electricity generation. Of all infrastructure projects we can only think of nuclear plants which may have a comparable spatial impact (with a comparable magnitude only in a case of a meltdown, though; the five largest power plants worldwide are all hydroelectric ones (Platts, 2015)). Thus, a universal framework may conceptualize dams' spatial social impacts too narrowly.

- Dams are among the most long-lived infrastructure projects, and social impacts can be considered over the entire operational timeframe (for instance, Takesada (2009) has studied the social impacts of Japan's Ikawa Dam 50 years upon resettlement). Indeed, dams may run for over 100 years, e.g. the construction of Arizona's still 
functioning Theodor Roosevelt Dam was completed 104 years ago (SRP, 2015), whereas, for instance, a coal-fired power plant may only last for 30 years (Cleetus et al., 2012). We acknowledge that these long-term impacts are currently not accounted for in commercial SIAs, but these long-term impacts can and should be of scholarly interest (020042015; see next section for details on this code) and thus should be included in a scholarly framework. However, a universal framework may ignore them.

We believe that only a specific framework on the social impact of dams ensures that these three peculiarities of dams are captured. Such a social impact framework, the focus of this paper, may then be considered as one pillar of a holistic framework on the impacts of dams. The holistic framework would also consider dams' environmental impacts; in practice, a commercial SIA (possibly informed by a scholarly framework) would usually be carried out as part of an environmental impact assessment (EIA) due to the interconnectedness and environmental and social issues (EIA) (Slootweg et al., 2001; Vanclay et al., 2015).

\section{Frameworks on the socialimpactofdams}

\subsection{Methods}

We attempted to create a representative sample of scholarly literature utilizing a framework when analyzing the social impact of dams. The initial sample of articles on the social impact of dams was generated via a three-step-process, conducted in early 2015. (To enhance readability, we refer to every piece of literature as an 'article' for the remainder of this paper. However, an 'article' may also encompass a report, book, book chapter or dissertation.)

Firstly, keyword searches were undertaken in seven databases: Thomson Reuters' Web of Science, the University of Oxford Search Oxford Libraries Online (SOLO), Elsevier's Scopus, ProQuest, Columbia International Affairs Online (CIAO), OpenGrey and Anthropology Plus. Searches included any scholarly journal articles, gray literature, book chapters and books that featured combinations of the keywords - social impact, social effect, human effect, resettlement, forced migration, agricultural productivity, dam and hydropower - as well as various plural forms of the keywords at hand. No starting date was set. Searches were not restricted to any particular discipline.

Secondly, experts in the field were invited to double-check and possibly add articles to this initial sample. Thirdly, these experts identified key pieces of literature on the social impact of dams. The bibliographies of these key pieces were added to our sample. Bibliographies of recent dissertations on the topic were also included, as well as articles which are allegedly key pieces of literature on the topic according to the International Association for Impact Assessment (IAIA, 2014).

Overall, we included the bibliographies of Lerer and Scudder (1999); Strobl and Blanc (2013), and Tullos et al. (2010) as well as all articles published by the journal Water Nepal to our sample. These inclusions were based upon recommendations of experts in the field. Furthermore, we included the bibliographies of the recent dissertations by Matthews (2013) and Plummer (2013) as well as the bibliographies by Égré and Senécal (2003) and Tilt et al. (2009), key pieces of literature on the topic according to IAIA (2014), to our sample.

The initial sample based upon this three-step-process comprised 1641 articles. We then refined this sample, removing any article from the sample if at least one of the six criteria below was met:

- Repetition: Pieces appearing more than once in the initial list;

- Focus: Pieces unrelated to the social impacts of dams ${ }^{1}$;

\footnotetext{
${ }^{1}$ Whenever we were not entirely certain - based upon reading the abstract and skimming the body of the article - if the article in question was truly unrelated to the social impact of dams, we chose to include it in the sample. We would then only exclude it based upon an in-depth-review of the article during the coding process.
}

- Language: Pieces not published in English or German;

- Popular press: Pieces on the topic published in the popular press, e.g. Wall Street Journal, the New York Times;

- Conference reports: Pieces related to the social impact of dams, but only summarizing the outcomes of conferences; or,

- Date of publication: Pieces published prior to $1990{ }^{2}$

The refined sample based upon these criteria comprised 217 articles. Each of these articles was then reviewed in-depth to examine if a framework was adopted. Herein, it was not relied upon the use of the term 'framework' (substitutes accepted were (inter alia) 'approach', 'model' or 'assessment'); rather, it was searched for an explication of a system (depicted either graphically or in narrative form), as suggested by Miles and Huberman (1994), that guided scholarly analysis and that usually would be explicated prior to presenting research results. Whereas this may sound vague at first sight, we found it to be evident for most articles if a framework was used or not. For instance, Wang et al. (2013, p. 133) write that "we introduce a framework of wealth analysis"; while Zhang et al. (2013) visualize their framework in a figure. All 217 articles in our sample were reviewed by two scholars to enhance reliability of our coding on the presence or absence of a framework. 55 articles containing a conceptual framework were eventually identified via this approach (20\% of these are gray literature, e.g. Master's theses, working papers or conference proceedings; various books are also included in this sample). An article would not be excluded from the eventual sample if the framework used in the article was already found in a previous article. All articles featuring a framework according to this approach are listed in the Appendix A.

We do not presume to have collected in this sample all articles on the social impact of dams which adopt a framework. However, we believe, given the systematic approach adopted, we have identified a set that is fairly representative of the work carried out by the research community.

Systematically creating a collection of scholarly articles on the social impact of dams constituted the starting point of a larger research project investigating various socio-economic impacts of dams. More than 100 semi-structured interviews have been carried out for this project to date. Interview partners are international donors, policy-makers, scholars, consultants, dam developers, NGOs as well as local communities. The first phase of interviews was carried out during field research in Myanmar, Thailand and Singapore from June to August 2015, at the 2015 World Hydropower Congress in Beijing in May 2015 and via telephone from April to August 2015. A second phase of data collection commenced in February 2016. We acknowledge that these interviews also informed this paper. However, only those interviews directly cited in this paper are listed in the Appendix A. A full (anonymized) list of interviews is available upon request. Given the sensitive nature of the topic, all interviewees were assured anonymity. Thus, all interviews are coded with the first letter indicating the type of interview ( $\mathrm{T}$ for telephone, $\mathrm{F}$ for face-to-face, $\mathrm{O}$ for online survey/e-mail) and the sequence of numbers indicating the date.

\subsection{Frameworkintheliterature}

Three observations stand out when first examining the overall sample.

Firstly, we observe that frameworks are not used routinely in scholarly literature on the social impacts of dams with only 55 (25\%) of the 217 articles containing a framework, as outlined in Section 3.1. A key reason may be the dominance of anthropological research in our

\footnotetext{
${ }^{2}$ We chose to exclude pieces published prior to 1990 for two reasons. First, we feared that we may not be able to gather a representative sample of articles published more than 25 years ago since many of these are not digitized yet. Second, we assume that frameworks from influential articles published prior to 1990, e. g. Scudder and Colson (1982), would be reflected in the sample with post-1990 articles in any case.
} 
sample; an important stream of the literature is from anthropology, which has been claimed as "the foundation discipline of developmentforced displacement and resettlement (DIDR) research" (Oliver-Smith, 2009, p. 6, cited in: Price, 2009, p. 266). Anthropologists with a focus on DIDR research mostly embrace an inductive, 'thick description' and qualitative research approach focused on the resettlement area which renounces the use of frameworks, largely due to the possible limitations of frameworks outlined in Section 2.1 (Lewellen, 2003).

This explanation hypothesis is reflected in our sample of articles on the topic at hand. Of those articles taking into account impacts in the resettlement area, largely to be counted within anthropological DIDR research, only $24 \%$ used a framework. As a comparison: $31 \%$ of articles taking into account regional and country social impacts used a framework, 36\% of articles considering downstream impacts and 39\% of those considering upstream impacts. These articles largely represent non-anthropological research.

Secondly, we observe for those articles containing a framework that no general agreement and common ground has been established yet regarding a framework for the social impact of dams. The 55 published works contain 27 different frameworks. The vast majority of these articles were published in the past 10 years (73\%). Only 15 of the articles (27\%) were released from 1990 to 2005, as depicted in Fig. 1. This growth is in line with the growth of the overall literature on the topic at hand: Scudder (2011) notes that research on DIDR has been growing rapidly in the past 50 years. Esteves et al. (2012) confirm this trend for the recent broader SIA literature finding 120 SIA articles for 1993 and 624 articles for 2010. This trend is also documented by Vanclay (2015) examining changes in the impact assessment family from 2003 to 2014 .

Thirdly, we note that the frameworks that are identified by scholars or practitioners as important to the field are not necessarily employed in analyses in the published scholarly literature. Numerous authors mention the relocation framework (RF) by Scudder and Colson (1982) as the key reference framework on the topic. Wilmsen et al. (2011a, p. 3) state that "the fundamental analyses of involuntary displacement were made by Scudder \& Colson (1982). However, RF is actually not employed in a single empirical article we identified - indicating that it may not be that important, after all. Meanwhile, the Hydropower Sustainability Assessment Protocol (HSAP) is mentioned by practitioners as the most important practitioners' framework on the social impact of dams (T23042015a; T23042015b), and has been reported to have been used by SIA consultants 24 times in various dam projects since 2011 (T30042015d). However, the framework only appears once in our set of articles, possibly reflecting a divide of the scholarly and practitioners' discourse. Indeed, none of the more than 100 practitioners we interviewed as part of our broader, currently ongoing research project actually mentioned a single scholarly framework on the topic at hand.

Our critical review of different frameworks on the social impact of dams particularly focuses on those frameworks that appear at least three times in our set of articles as well as RF by Scudder and Colson (1982) as the alleged foundational framework for the scholarly literature. While cost-benefit-analysis (CBA) is identified and counted in Fig. 1 as a single framework, various CBA approaches actually prevail. Hence, CBA is not included in the review. We call the five chosen frameworks for review our reference frameworks.

We provide a brief overview regarding our reference frameworks below. Additional details and visualizations regarding these frameworks are to be found in the Appendix A.

On our five reference frameworks:

- The Relocation Framework (RF) by Scudder and Colson (1982): RF is a four-stage-model describing "how the majority of resettlers can be expected to behave during a successful resettlement process" (Scudder, 2006, p. 31). Its four stages are (i) planning \& recruitment, (ii) adjustment \& coping, (iii) community formation \& economic development as well as (iv) handing over \& incorporation;

- The Impoverishment Risks and Reconstruction (IRR) Model by Cernea (1990): IRR describes seven different impoverishment risks through displacement. These are (i) landlessness, (ii) joblessness, (iii) homelessness, (iv) marginalization, (v) food insecurity, (vi) morbidity, and (vii) social disarticulation;

- The Sustainable Livelihoods Framework (SL) by DFID (1999): SL depicts the main factors influencing people's livelihoods (their livelihoods assets), desirable livelihood outcomes as well as different livelihood strategies to reach these outcomes via the outlined assets. At its core is the asset pentagon containing five key components, namely (i) human capital, (ii) social capital, (iii) natural capital, (iv) physical capital as well as (v) financial capital;

- The World-Commission-of-Dams-Framework (WCD) by WCD (2000): WCD outlines seven strategic priorities for sustainable dam construction. These are (i) gaining public acceptance for the dam project, (ii) comprehensive options assessment, (iii) addressing existing dams, (iv) sustaining rivers and livelihoods, (v) recognizing entitlements and sharing benefits, (vi) ensuring compliance, (vii) sharing rivers for peace, development and security;

- The Integrative Dam Assessment Model (IDAM) by Kibler et al. (2012): IDAM is a multidisciplinary model on the social impact of dams

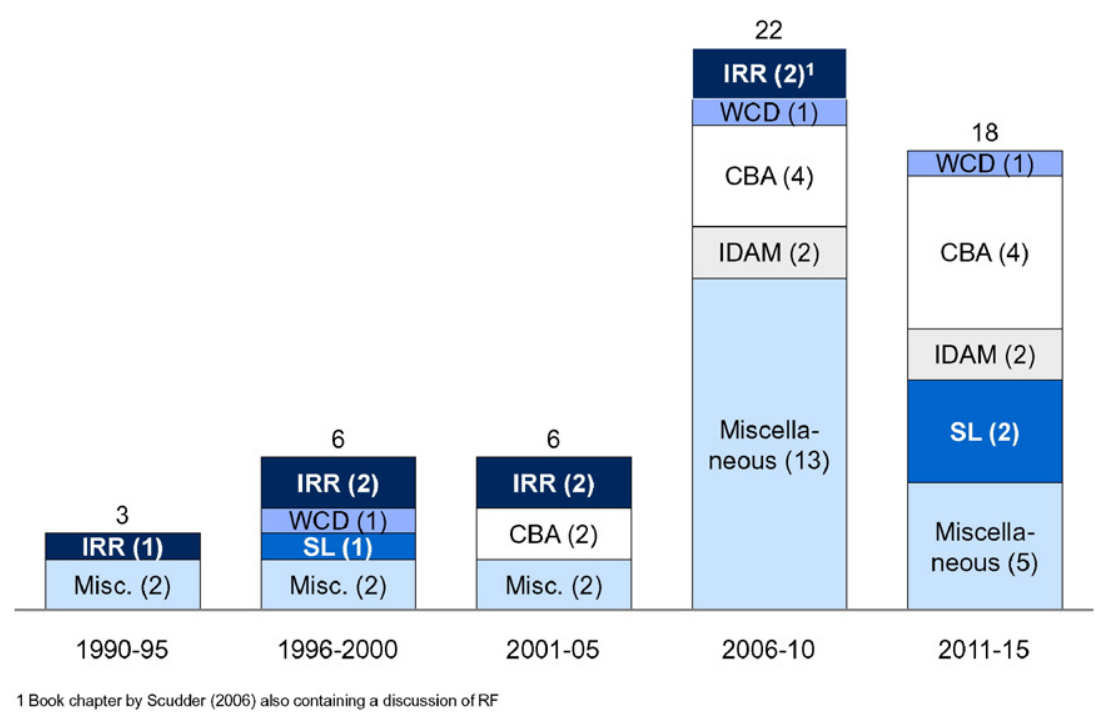

Fig. 1. Usage of frameworks on the social impact of dams over time. 
spelling out 7 socio-economic components of impact, 7 geo-political components of impact as well as 7 bio-physical components of impact. The 7 socio-economic components are (i) social cohesion, (ii) cultural knowledge and behavior, (iii) material culture, (iv) infrastructure, (v) income, (vi) wealth and (vii) macro-impacts.

We note that three of these reference frameworks (namely RF, IRR and SL) are not specifically about dams' social impacts, but displacement and livelihoods overall. Thus, discussions in the next session regarding limitations of existing frameworks are not meant to be primarily discussions about limitations of these frameworks overall, but frequently only refer to limitations that may occur when applying these frameworks specifically to dams' social impacts. Our criticism of the applications of these frameworks regarding dams thus underscores the need for a specific framework on the social impact of dams. We point out that RF, IRR and SL may still be extremely helpful frameworks in a variety of instances beyond the study of dams' overall social impacts.

\subsection{Limitations of existing frameworks in the context of dams - a critical review}

Upon systematically reviewing the different frameworks within the literature and their usages (with a particular focus on our five reference frameworks) we identified five key limitations which would need to be addressed in a new framework on the social impact of dams in our point of view: (1) a limited spatial perspective; (2) a limited temporal perspective; (3) a bias towards either positive or negative impacts; (4) an incomplete list of social impacts; (5) missing interlinkages between different impacts. These limitations are discussed in more detail below. We note that limitations (2), (3) and (5) should be addressed not only in a framework specific to dams, but also in an overall framework on displacement and livelihoods in our point of view.

\subsubsection{Limitedspatialperspectiveonsocialimpacts}

"SIA needs to look beyond the immediate community out into the broader region. SIA has tended to concentrate on communities and projects with a well-defined geography boundary" (Harvey, 2011, p. 17). This criticism regarding SIA also applies for the key scholarly frameworks on the social impact of dams. All reference frameworks do consider, from a spatial perspective, the construction and resettlement areas. However, particularly RF and IRR have repeatedly been criticized for missing, as noted by Scudder (2012, p. 44), "the wider political economy at the national and international level" when applied to study dams' social impacts (admittedly, RF and IRR were specifically designed to study resettlement impacts, not overall spatial impacts of infrastructure development. Thus, this criticism may deem to be unfair). WCD accounts for regional, country and global impacts via its principle Sharing Rivers for Peace, Development \& Security. The SL framework does not spell out any spatial dimension. However, its empirical applications within research on the social impact of dams focus on those resettled. If various spatial impacts areas were included, scholars may adopt a broader spatial focus in their analyses, we hypothesize.

Besides impacts on the resettlement, country and global level, dams also impact upstream and downstream river populations. Cernea (2004, p. 6) points out that "downstream impacts have been understudied and overlooked by dam planners, as well by the authors of many [SIAs]". Yet the IRR, developed by Cernea (1990), does not explicitly account for such downstream impacts as it was developed as a framework to study displacement; downstream impacts are also not explicated by RF, SL and IDAM (IDAM's negligence of downstream impacts is particularly surprising since this framework was specifically created to study dams' social impacts). WCD only take into account this spatial dimension in its overall report, not its seven strategic priorities. If downstream impacts are neglected in the framework (and, subsequently, in the social impact analysis), various positive social impacts of dams may not be accounted for. For instance, Duflo and Pande (2007) - utilizing a CBA - find that agricultural production increases and vulnerability to rainfall shocks declines downstream if a large irrigation dam is constructed. Strobl and Strobl (2011) echo this finding - also via a CBA showcasing that large dams increase agricultural productivity downstream by $1 \%$.

Greathouse et al. (2006) argue that upstream impacts (e.g. restrictions regarding water withdrawal from a river in order to fill the reservoir) have been even more understudied than downstream impacts. Indeed, only WCD features an explicit discussion of upstream social impacts within its report. The authors particularly point out the difficulties of balancing upstream and downstream interests.

The most detailed description of dams' social impacts from a spatial perspective that we found in the body of literature is compiled by Lerer and Scudder (1999). The authors list in their article on health impacts of large dams seven spatial dimensions of social impact, namely (i) upstream catchment and river, (ii) reservoir area, (iii) downstream river, (iv) irrigation areas, (v) construction activities, (vi) resettlement areas and (vii) country, regional and global. This comprehensive spatial categorization has not been picked up by any subsequent frameworks or scholarly articles, though.

A new framework on the social impact of dams ought to comprehensively spell out social impacts at every spatial dimension. Explicating spatial dimensions may particularly encourage looking beyond displacement and resettlement impacts. Indeed, it has been decades since it was noted that resettlement "has probably received more attention than any other category of social impact" (Shields, 1974, p. 268); it is "largely considered the most severe form of social impact generated by dams" (Égré and Senécal, 2003, p. 216), but it is not the only relevant one from a spatial perspective.

\subsubsection{Limitedtemporalperspectiveonsocialimpacts}

Tilt et al. (2009, p. 256) note that "one of the most problematic aspects of conducting SIA of large dam projects is ensuring the analysis takes place at the proper temporal [...] scale". Plummer Braeckman and Guthrie (2015) also make this point particularly highlighting the scarcity of studies on dams' planning and design phase impacts.

These observations are reflected in our scholarly reference frameworks. Whereas all reference frameworks explicitly address social impacts occurring during the operation phase of a dam, a perspective on dams' social impacts over time is only to be found within WCD and RF. WCD addresses planning and design impacts via its principle Addressing Existing Dams. RF accounts for these impacts via its stage Planning \& Recruitment as well as its stage Adjustment \& Coping which largely overlaps with the construction phase of a dam.

$\mathrm{RF}$ is the only reference framework that encourages consideration of second generation impacts of dams within the operation phase. These long-term impacts are reflected in RF's fourth stage, Handing Over \& Incorporation. Scudder (1997a, p. 658) repeatedly complained regarding "a paucity of research [...] designed to assess long-term impacts".

Among our total set of frameworks HSAP is one of the few frameworks beyond the RF and WCD explicitly taking into account dams' social impact over time. HSAP conceptualizes dams' social impacts during early stage, preparation, implementation and operation for dam developers.

Admittedly, the non-inclusion of a temporal perspective within a framework does not necessarily imply that a framework will only be used for the phase the framework is focused on. For instance, Tullos et al. (2013) investigate social impacts of dams on the Nu River in the planning \& design phase via IDAM, although this framework does not explicitly include this temporal dimension.

However, Sayatham and Suhardiman (2015) - analyzing social impacts of the Nam Mang 3 Dam in Laos via SL - solely focus on the operation phase, though, just as SL would suggest; planning and design as 
well as construction phase impacts are largely neglected, although these may also be considered significant impacts when holistically considering dams' social impacts - which the authors seemingly attempt to do. We hypothesize that planning and design phase as well as construction phase impacts may have been considered by the authors if the framework employed had explicated different temporal dimensions of social impact.

A new framework on the social impact of dams would need to adopt a comprehensive view regarding social impacts over time. Herein, the framework ought to serve as a constant reminder to scholars to think through dams' social impact from the planning and design phase until the operation phase - which may even include next generation social impacts.

\subsubsection{One-sidedviewregardingsocialimpacts}

In his introduction to SIA, Barrow (2000) notes the scholarly tendency to stress negative impacts when studying the social impacts of infrastructure development. Vanclay (2002, p. 189) iterates this observation noting that "despite rhetoric in SIA about considering the benefits of planned interventions $[. .$.$] that there is no consideration given to the in-$ dicators that would be necessary to describe the positive benefits of projects".

These observations only partly hold true for our reference frameworks. Among our reference frameworks, only IRR is solely focusing on negative social impacts listing seven likely impoverishment risks for those resettled. The empirical application of this framework tends to reflect this original connotation. For instance, Dwivedi (1999) employing IRR - largely focuses on negative social impacts when investigating India's Sardar Sarovar Dam.

McDonald-Wilmsen \& Webber (2010, p. 145) argue that WCD may also lean more towards negative impacts criticizing that there is no "adequate consideration [is given] to the rights of communities to benefit from irrigation water, flood control or electricity" within WCD. The other reference frameworks allow for both positive and negative impacts, whereas two frameworks ( RF and SL) lean more towards positive impacts. Indeed, RF has been repeatedly criticized, as acknowledged by Scudder (2006), regarding its fourth stage which argues there would eventually be a favorable outcome for those resettled. The livelihood outcomes stated by SL are also decidedly positive (e.g. more income, increased well-being, reduced vulnerability).

Within our reference frameworks, only IDAM attempts to be entirely objective stating for each category of social impact a positive as well as a negative outcome. This objectivity is also reflected in its numerous empirical applications. For instance, Tullos et al. (2010) discuss in-depth both possible positive and negative impacts of dams in their paper on different hydro development scenarios in China.

A new framework on the social impact of dams also ought to emphasize that impacts may be both positive and negative.

\subsubsection{Incomprehensivelistofsocialimpacts}

Tilt et al. (2009) point out that no standard set of social impact variables to study is agreed upon; many investigations on the social impact of dams would be unique from a component perspective. Again, this observation is largely reflected in our reference frameworks.

Concretely, many reference frameworks (RF, IRR \& SL) neglect dams' infrastructure impacts, particularly flood control. This is of little surprise since these frameworks are not specifically about dams, while flood control is an impact specific to dams, though, as outlined in Section 2.2. Whereas livelihood impacts (with the exception of health and nutrition) are largely included, cultural change impacts are also missing in two reference frameworks (RF, IRR).

Among our reference frameworks, SL has been lauded by scholars regarding its conceptualization of social impact components. Supposedly, "[SL] provides a robust conceptual framework for the development of appropriate social indices" (Coakes and Sadler, 2011, p. 339). We acknowledge that SL's omission of flood control impacts may not always lead to an omission of flood control impacts in SL's empirical application. For instance, Wilmsen et al. (2011b)- utilizing (inter alia) SL - discuss flood control benefits of the Three Gorges Dam in their analysis.

Within our total set of frameworks, Wang et al. (2013) present a structure that we find particularly compelling when thinking about social impact components. In their analysis on the social impacts of large dams on the Upper-Mekong River in China, the authors argue there would be three classes of wealth, namely, material wealth (i.e. farmland, houses, livestock, cash crops, forests), embodied wealth (i.e. wealth implicitly carried by a person such as agricultural skills, fishery skills) and relational wealth, including both social infrastructure (a person's social network, language, customs, and traditional festivals), as well as physical infrastructure (transportation conditions, healthcare, and education resources). This structure is not picked up by any other authors, though.

WCD does not outline most impact components in its seven strategic priorities, but only its overall report. Possibly as a consequence, Luwa (2007) - adopting (a modified version of) WCD - misses several components in the analysis of social impacts, e.g. infrastructure impacts such as roads and transportation as well as community impacts such as cultural change.

Regarding community impacts, social cohesion aspects are addressed in all of our reference frameworks, while cultural change is largely neglected within RF and IRR - this is an impact, though, that should be included even in a general displacement framework in our point of view. Indeed, RF and IRR were repeatedly criticized for missing "issues of human rights and cultural reconstruction" (Scudder, 2012, p. 44). Possibly as a consequence of this omission, Dwivedi (1999) - utilizing IRR when analyzing the social impacts of the Sardar Sarovat Dam - does not discuss any cultural change implications.

Within our total set of frameworks, the theory about the psychosocio-cultural disruptions of involuntary displacement by Downing and Garcia-Downing (2009) is particularly dedicated to cultural change impacts. The authors particularly warn to follow the "compensation-isenough-fallacy', i.e. limiting analyses on the social impact of dams on mitigating livelihood impacts.

A new framework on the social impacts of dams ought to comprehensively map all components of dams' social impacts including those difficult to operationalize, e.g. social cohesion or cultural change. This listing of components may provide a valuable starting point for scholars and practitioners alike to start formulating a comprehensive set of impact hypotheses.

\subsubsection{Limitedacknowledgementofcausalimpactloops}

Tilt et al. (2009) point out dams may induce both direct and indirect impacts. This notion refers to the interlinked nature of dams' social impact components. E.g. the resettlement of a village may impact its community which, in turn, impact the village's livelihood. Indeed, not everybody to be resettled may move to the resettlement location, but a few villagers may choose to move to the city instead. If those moving to a large nearby city are the most skilled, the villagers may suddenly lack the capabilities to run various businesses. Meanwhile, changes in infrastructure, also induced by resettlement, may also impact a village's community. For instance, the resettled village may suddenly be connected to the electricity grid, which, in turn, may change the preferred free time activities of the villagers, a social cohesion impact.

Conceptualizing these causal impact loops and impact paths is a complex endeavor which the reference frameworks largely do not address. Particularly IDAM's attempt to map the interconnectedness of different impact components seems confusing. For instance, IDAM considers flood control impacts as a domestic shock within geopolitical impacts, while impacts on roads and transportation are listed within social cohesion. Health impacts are counted within biophysical impacts. 
No explanation was found regarding this sorting and the likely interconnectedness of social impacts.

Possibly due to this surprising ordering of different impact components, Hennig et al. (2013, p. 594) argue that IDAM would be "presently methodologically not mature". IDAM empirical applications corroborate that the framework's components may require additional enhancement. When Tullos et al. (2010, p. 89) report on the usage of IDAM in an academic environment, they find that many parts of the framework were "not well understood by stakeholders".

Whereas IRR's mapping of different impact components may seem more succinct than IDAM's at first sight, the interconnectedness of these components is also neglected. Indeed, all components are conveyed as separate. However, IRR's landlessness, joblessness, homelessness and food insecurity, for instance, may result in marginalization which, in turn, may lead to morbidity; the author's framework does not discuss these possible relations. The importance of linking the different components of social impact is well illustrated by Bui and Schreinemachers (2011). Whereas the authors - employing SL - comprehensively discuss particularly livelihood impacts of a resettlement program in northwestern Vietnam, a discussion on the livelihood impacts on cultural change in the community is largely lacking, for instance.

Of all frameworks at hand, WCD may address and discuss different causality loops in the most comprehensive manner. However, this discussion comes at the expense of providing a succinct framework. Indeed, Beck et al. (2012, p. 2) already note that "WCD is complex and promotes the use of three global norms, five core values, five key decision points, seven strategic priorities, 33 associated policy principles, and 26 guidelines in implementation and advocacy of dam-related activities".

Indeed, WCD is not an actual framework guiding the scholar regarding prioritization, but rather a comprehensive report counting 404 pages. Accordingly, industry claimed that no more dams would be built if the WCD framework was adopted since it would be simply overwhelming (T30042015d). The issues of adopting WCD in analyses are well illustrated by Chen (2013). Due to the complexity of the overall framework, the author chooses to only focus on WCD's seven strategic priorities for sustainable dam construction outlined. Herein, the author largely mentions all relevant social impact components, but the analysis lacks a detailed description of the interrelatedness of these components and impact paths, although these are discussed within WCD.
Admittedly, a new framework on the social impact of dams may not be able to spell out all likely causality loops and impact paths on the social impact of dams comprehensively. After all, the interconnectedness of different social impacts is likely to be highly context-sensitive. However, a framework ought to raise scholars' awareness that social impact components are not separate, but interlinked. It must encourage scholars to start hypothesizing on likely interlinks.

\section{Conceptualizingthesocialimpactofdams}

We developed a new framework (called 'matrix framework') on the social impact of dams which addresses the five limitations outlined in the previous section. This new framework is also to be understood as an aggregation of different frameworks on social impact since it attempts to include the various dimensions and components of impact identified in the scholarly literature. Since we (believe we) are not leaving out any dimensions or components previously identified by scholars, but attempt to integrate the various scholarly findings in our framework, we hope that this framework will be accepted by many academics; we hope that this aggregation eventually may help to foster agreement regarding the overall set of variables to consider when studying dams' social impacts. Whereas none of the dimensions or components outlined in our framework may be new by itself, the combination of different frameworks ought to ensure a more holistic and succinct perspective specifically addressing the social impact of dams.

\subsection{A newframeworkfor analysis}

Our suggested framework, the matrix framework, conceptualizes the social impact of dams from a dimension and component perspective. Dimensions are space, time and value. Components are infrastructure, livelihood and community. A visualization of this framework is depicted in Fig. 2.

Within the space dimension, we suggest thinking about dams' social impact from an upstream, downstream, resettlement as well as country and global perspective. Planning and design, construction and operation may be the key time dimensions to be considered. In addition, all impacts may be positive or negative.

Nine different components of social impact are outlined within our framework. These are clustered in infrastructure, livelihood and community impacts. Within infrastructure, electricity, irrigation and water, flood control as well as roads and transportation are depicted.

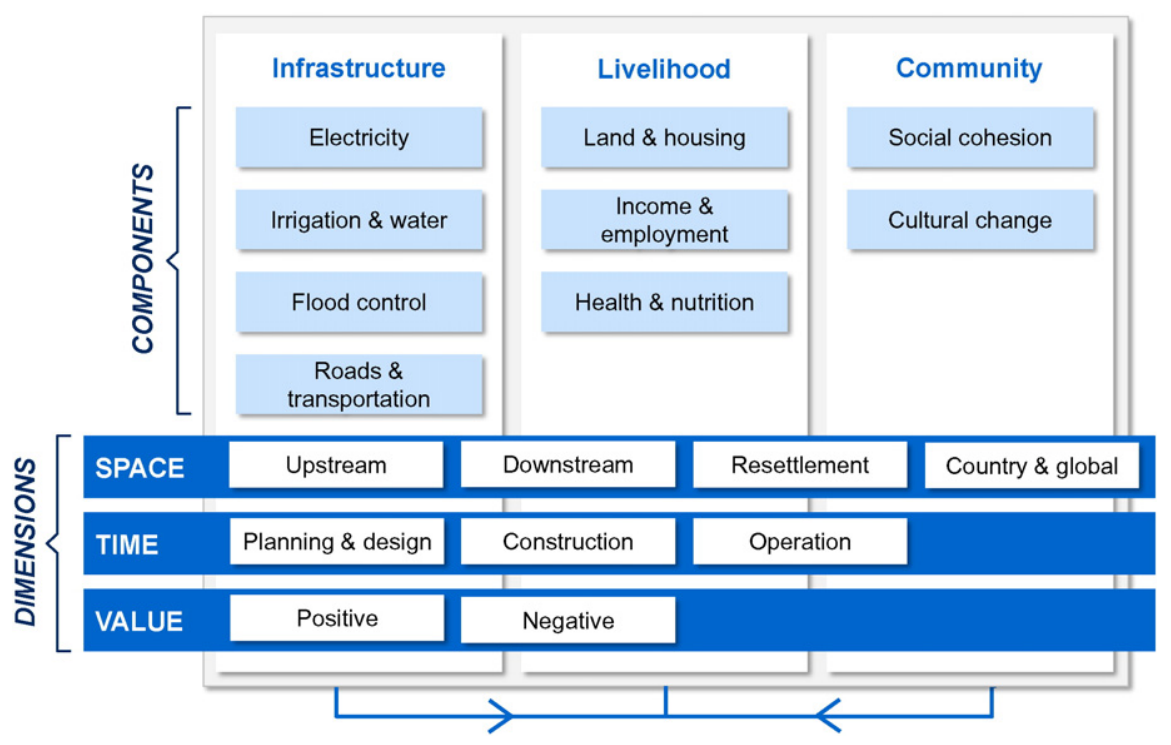

Fig. 2. Suggested matrix framework on dams'social impacts. 
Livelihood impacts are land \& housing, income and employment as well as health and nutrition; community impacts are social cohesion and cultural change.

Our components of social impact are variables to consider when assessing the social impact of dams. The dimensions of social impact are the variables' context. Accordingly, any social impact component may occur alongside the different dimensions of social impact. The components of social impact are not mutually exclusive, but rather sequential. Changes in infrastructure may induce changes in livelihood which, in turn, may induce changes in the community. At the same time, changes in community may induce changes in livelihood which, in turn, may induce changes in infrastructure.

Evidently, our framework adopts the perspective of people impacted by the dam. Additional units of analysis (regarding their impacts on the different components within the different dimensions outlined) may be the private sector, namely dam developers, banks and related companies, civil society, namely NGOs, both local as well as international, the government, namely the domestic government, foreign governments as well as international donors.

Additional details on each sub-dimension and sub-component as well as the key sources for these components are given in Table 1. Additional details on the sources of the framework are also given in Table 1 as well as the Appendix A.

\subsection{Contributionsandlimitationsofsuggestedframework}

We believe our suggested new matrix framework addresses the five limitations outlined in the previous section. First, our framework ensures a more comprehensive analysis regarding the social impact of dams from a spatial perspective. Second, our framework adopts a comprehensive view regarding social impacts over time. Third, our framework emphasizes that impacts may be both positive and negative. Fourth, our framework comprehensively maps all specific components of dams' social impacts. Fifth, our framework encourages scholars to consider the interlinked nature of these components.

Since causality loops and complex impact paths are omnipresent within the social impacts of dams, reflecting upon them upfront may lead to more comprehensive social impact analyses. We would suggest that researchers employing the framework develop hypotheses for each impact component within the framework and then, in a second step, start considering possible interrelations of these initial and separate impact hypotheses. Because impact paths are highly context-sensitive, it is likely than many additional causality loops would only be detected during field work.

When developing hypotheses via our framework not all dimensions and components outlined must be considered. For instance, a scholar may choose to only investigate positive and negative upstream impacts during the planning and design phase of a dam project. Within these impacts, s/he may choose to particular investigate infrastructure and livelihood impacts. However, it is key that the scholars explicates and reflects upon these exclusions upfront in order to position the analyses and the results for the reader. For instance, a scholar investigating upstream infrastructure and livelihoods impacts of a dam in the planning and design phase may find that these are largely negative. However, the scholar should then point out that this finding does not convey that the overall impact of the dam is negative - resettlement, downstream, country and global impacts (both positive and negative ones) alongside the various temporal dimensions of dams' social impacts would also need to be taken into account for an overall judgment. All too often scholars judge a dam project overall when only having studied a very few dimensions and components of the project.

In Table 2 we attempt to map the dimensions and components of our framework against the key reference frameworks identified in the literature to highlight the additional contribution our framework makes specifically to analyses on dams. We present this comparison specifically on dams, while acknowledging the limitations of this mapping. As discussed previously, the key reference frameworks are not all specific to dams, so this analysis is focused on their applicability to address the social impacts of dams holistically. Due to the different terminologies employed in the different frameworks, we sometimes found it ambiguous to decide if one of our dimensions and components of social impact was truly reflected in the reference frameworks. Thus, the comparison is to the best of our knowledge, but still (at least partly) subjective.

\section{Conclusion}

Frameworks matter. Indeed, the results of a scholarly analysis are significantly interlinked with and frequently the direct result of the framework employed. The framework provides the perspective on the question at hand; it determines which components and dimensions of

Table 1

Details and sources of suggested matrix framework

\begin{tabular}{|c|c|c|c|}
\hline \multicolumn{2}{|c|}{ Matrix framework } & \multirow{2}{*}{$\begin{array}{l}\text { Details } \\
\text { Upstream: Upstream catchment or river area within the country of the dam(s) at question } \\
\text { Downstream: Downstream area within the country of the dam(s) at question } \\
\text { Resettlement: Where construction activities take place, the reservoir, close-by irrigation and resettlement areas } \\
\text { Country \& global: Regional, country or global level. (e.g. regions such as Oregon, United States, Yunnan } \\
\text { province, China). Also includes trans-boundary impacts }\end{array}$} & \multirow{2}{*}{$\begin{array}{l}\text { Source } \\
\text { Lerer and Scudder (1999) }\end{array}$} \\
\hline Dimensions & Space & & \\
\hline & Time & $\begin{array}{l}\text { Planning \& design: Including times even prior to the project design until the start of construction } \\
\text { Construction: Comprising the entire phase of actual dam construction } \\
\text { Operation: From the completion of dam construction onwards. Focus may also be on } \\
\text { next-generation-social-impacts }\end{array}$ & $\begin{array}{l}\text { Scudder and Colson (1982) } \\
\text { IHA (2010) }\end{array}$ \\
\hline & Value & $\begin{array}{l}\text { Positive: Any positive impacts within the different components } \\
\text { Negative: Any negative impacts within the different components }\end{array}$ & Kibler et al. (2012) \\
\hline \multirow[t]{3}{*}{ Components } & Infra-structure & $\begin{array}{l}\text { Electricity: May come from any source, e.g. the dam, boomtown infrastructure } \\
\text { Irrigation \& water: Also includes crop outputs, fishing, water provision, leakage and any impacts related to } \\
\text { drought and drought mitigation as well as soil erosion } \\
\text { Flood control: Also includes flood mediation aspects as well as flash floods, e.g. due to dam failure } \\
\text { Roads \& transportation: Also includes impacts on sea roads and sea navigation }\end{array}$ & $\begin{array}{l}\text { Kibler et al. (2012) } \\
\text { Wang et al. (2013) } \\
\text { WCD (2000) }\end{array}$ \\
\hline & Commu-nity & $\begin{array}{l}\text { Land \& housing: Includes impacts on livestock and cash crops } \\
\text { Income \& employment: Includes monetary benefit-sharing impacts and royalty benefits, changes in (income) } \\
\text { inequality, poverty reduction, economic growth as well as tourism development and educational impacts } \\
\text { Health \& nutrition: Also comprises food security aspects (e.g. lost fisheries grounds), loss of life, water } \\
\text { sanitation, greenhouse gas and air pollution impacts }\end{array}$ & $\begin{array}{l}\text { Kibler et al. (2012) } \\
\text { Lerer and Scudder (1999) } \\
\text { Wang et al. (2013) }\end{array}$ \\
\hline & Livelihood & $\begin{array}{l}\text { Social cohesion: Includes impacts on social networks and status, capital and solidarity, happiness, social stress } \\
\text { and safety concerns, social costs of uncertainty, corruption, political stability, but also recreation } \\
\text { Cultural change: Includes impacts on tangible cultural assets, e.g. churches or pagodas, but also landscape loss }\end{array}$ & $\begin{array}{l}\text { DFID (1999) } \\
\text { Downing and Garcia-Downing } \\
\text { (2009) } \\
\text { Kibler et al. (2012) }\end{array}$ \\
\hline
\end{tabular}




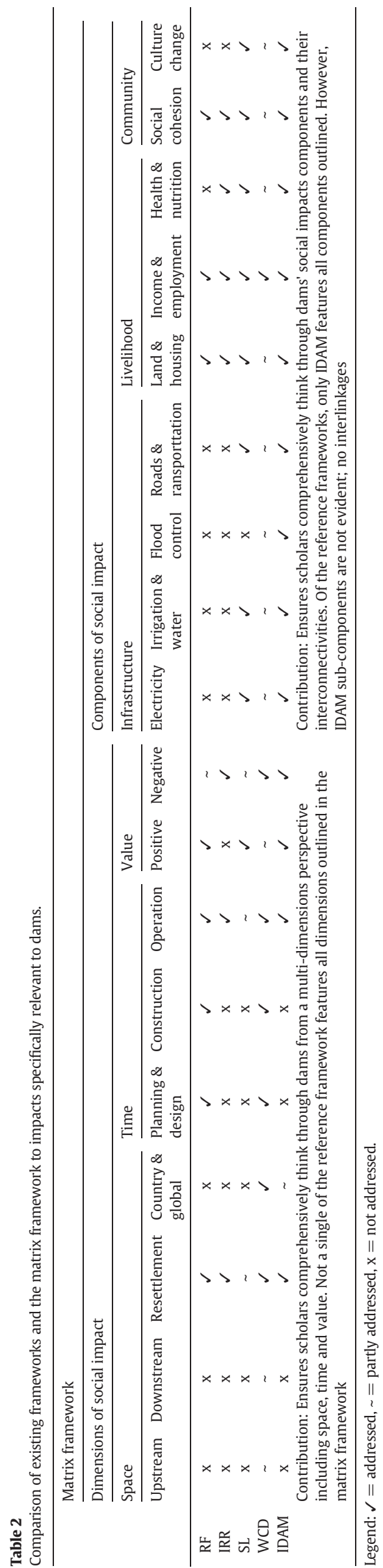

social impact to investigate - and which to exclude. For dam construction, an emotive and contentious topic, a comprehensive scholarly framework can help conceptualize the inherently complex and numerous issues involved with dam construction in a way that enables more transparent assessment of projects.

Within the field of research on the social impact of dams, we found that 27 frameworks have been used, yet none has been adopted as the key framework. Many of the frameworks have generally not been developed specially for dams, and may focus more specifically on one aspect such as resettlement. Five reference frameworks were selected as the focus for this review (the Relocation Framework (RF); the Impoverishment Risks and Reconstruction (IRR) model; the Sustainable Livelihoods Framework (SL); the World Commission of Dams Framework (WCD); and the Integrative Dam Assessment Model (IDAM). These frameworks provide vastly different perspectives on dams' social impacts. These differences, in turn, may undermine the consistency and credibility of analyses on the social impact of dams. For example, these reference frameworks largely neglect upstream, downstream as well as regional and global impacts (with the exception of WCD; the neglecting is unsurprising for RF and IRR which were specifically designed to study resettlement impacts). In addition, only two (RF and WCD) consider dams holistically from a time perspective. Within the reference frameworks, only IDAM objectively reports both positive and negative impacts. Frameworks not specific to dams, i.e. RF, IRR \& SL, largely neglect dams' specific infrastructure impacts, particularly flood control. Whereas livelihood impacts are largely included, cultural change impacts are also missing in two of the reference frameworks (RF, IRR). Overall, the frameworks do not facilitate the consideration of the interlinkages between different impact components.

Based on this review, we propose a new framework (which we call 'matrix framework') specifically for the social impact of dams which addresses limitations of the different frameworks and aggregates perspectives on the social impact of dams in order to unify our understanding on the topic at hand and to thus create a common ground for future scholarly analysis. Our framework indicates that assessments of the social impact of dams should start by simultaneously considering the dimensions (space, time and value) of social impact and the components (infrastructure, livelihood and community).We attempt to comprehensively map dams' social impacts via this framework, while encouraging scholars to consider the interlinked nature of these impacts.

A leading authority on the impact of dams on poor people was disappointed that "theoretical advances on dam-relevant research have been so slow" in recent decades (020042015). A reason may be the lack of commonly used frameworks. Too many scholars start their analysis from scratch and thus studies are frequently difficult to compare which prevents aggregation. As a result, knowledge on the social impact of dams cannot accumulate. If the suggested matrix framework was commonly employed, it would enable comparison of projects and may thus help advance scholarly understanding of the social impact of dams.

Furthermore, we imagine that a succinct scholarly framework on the social impact of dams may also help shape commercial SIA conduct. The particular framework suggested in this paper addresses many of the limitations found in contemporary SIA for dams, as outlined in Section 3. We are particularly concerned regarding SIA's frequent negligence of dams' downstream impacts. This seems to hold true especially for SIAs carried out in many developing economies (T22042015). Thus, this framework may also be understood as an encouragement for practitioners to think through dams' social impacts holistically from a spatial perspective - which includes considering downstream impacts. We also hope to raise awareness regarding the multitude of component impacts - ranging flood control to cultural change. Only a holistic view regarding dams' social impacts (which our framework attempts to encourage based upon a critical review and the aggregation of 27 existing frameworks) ensures that a project can be assessed objectively. 


\section{Disclosure statements}

No potential conflict of interest was reported by the authors.

\section{Acknowledgments}

This research was funded by Friedrich Naumann Foundation. We are grateful to Huw Pohlner for helping us identify articles containing a framework on the social impact of dams. We would also like to thank James Fenske, Nathanial Matthews, Christine McCulloch, and Judith Plummer for the suggestions regarding our sample of articles. We would also like to thank Judith Plummer and Matthew Walton for suggestions and comments on this paper. Furthermore, we are grateful to those providing feedback to this paper at the University of Sheffield RGS-IBG Forum Mid-Term Conference 2015 in March 2015, those at the University of Oxford Water Talk in May 2015 as well as those at HYDRO 2015 in October 2015. Lastly, we are also grateful to two anonymous reviewers from Environmental Impact Assessment Review for their constructive comments on this piece of work.

\section{Appendix A}

\section{A.1. Articlesonthesocialimpactofdamscontaininga framework}

Table 1

Articles on the social impact of dams containing a framework.

\begin{tabular}{|c|c|c|c|}
\hline \# & Author(s) \& year of publication & Publication & Framework \\
\hline 1 & Sayatham and Suhardiman (2015) & Water Resources and Rural Development & Sustainability livelihood framework \\
\hline 2 & Singer and Watanabe (2014) & Lakes and Reservoirs: Research and Management & Society-environment economy-framework \\
\hline 3 & Tajziehchi et al. (2014) & International Journal of Environmental Research & Cost-benefit analysis \\
\hline 4 & Bui et al. (2013) & Land Use Policy & Sustainability livelihoodframework \\
\hline 5 & Chen (2013) & Master's thesis & $\begin{array}{l}\text { World-commission-of dams-framework/rights, risks and responsibilities } \\
\text { approach }\end{array}$ \\
\hline 6 & Tullos et al. (2013) & Ecology \& Society & Integrative dam assessment model \\
\hline 7 & Kurniati et al. (2013) & Conference/Working Paper & Cost-benefit analysis \\
\hline 8 & Wang et al. (2013) & Journal of Environmental Management & Wealth framework \\
\hline 9 & Zhang et al. (2013) & Journal of Geographical Sciences & Social capital framework \\
\hline 10 & Beck et al. (2012) & International Journal of River Basin Management & Aggregated framework \\
\hline 11 & Kibler et al. (2012) & Report & Integrative dam assessment model \\
\hline 12 & Mirumachi and Torriti (2012) & Energy Policy & Cost-benefit analysis \\
\hline 13 & Qi and Altinakar (2012) & Journal of Water Resources Planning \& Management & Cost-benefit analysis \\
\hline 14 & Tajziehchi et al. (2012) & Polish Journal of Environmental Studies & Cost-benefit analysis \\
\hline 15 & Bui and Schreinemachers (2011) & $\begin{array}{l}\text { International Journal of Water Resources } \\
\text { Development }\end{array}$ & Sustainability livelihoodframework \\
\hline 16 & Strobl and Strobl (2011) & Journal of Development Economics & Cost-benefit analysis \\
\hline 17 & Wilmsen et al. (2011b) & Asian Studies Review & $\begin{array}{l}\text { Sustainability livelihoodframework/impoverishment risks and } \\
\text { reconstruction model }\end{array}$ \\
\hline 18 & Wilmsen et al. (2011a) & Journal of Environment and Development & Resources-strategies-outcomes-framework \\
\hline 19 & IHA (2010) & Report & Hydropower sustainability assessment protocol \\
\hline 20 & $\begin{array}{l}\text { McDonald-Wilmsen and Webber } \\
\text { (2010) }\end{array}$ & Water Alternatives & Discussion of frameworks \\
\hline 21 & Tullos et al. (2010) & Water Alternatives & Integrative dam assessment model \\
\hline 22 & Brown et al. (2009) & Journal of Environmental Management & Integrative dam assessment model \\
\hline 23 & $\begin{array}{l}\text { Downing and Garcia-Downing } \\
\text { (2009) }\end{array}$ & Monograph & Psycho-cultural risk model \\
\hline 24 & Kittinger et al. (2009) & EcoHealth & Millennium ecosystem assessment \\
\hline 25 & McNally et al. (2009) & Journal of Environmental Management & Powershed framework \\
\hline 26 & Rojanamon et al. (2009) & Renewable and Sustainable Energy Reviews & Participatory Framework on Social Impacts \\
\hline 27 & Tilt et al. (2009) & Journal of Environmental Management & Social Impact Assessment \\
\hline 28 & Brown et al. (2008) & China Economic Review & Cost-Benefit Analysis \\
\hline 29 & Erlanger et al. (2008) & $\begin{array}{l}\text { International Journal of Environmental Health } \\
\text { Research }\end{array}$ & Health Impact Assessment \\
\hline 30 & Bhatia et al. (2008) & Irrigation \& Drainage & Cost-Benefit Analysis \\
\hline 31 & Duflo and Pande (2007) & Quarterly Journal of Economics & Cost-Benefit Analysis \\
\hline 32 & Larson (2007) & Energy & Cost-Benefit Analysis \\
\hline 33 & Luwa (2007) & Master's thesis & $\begin{array}{l}\text { World-Commission-of Dams-Framework/Rights, Risks and Responsibilities } \\
\text { Approach }\end{array}$ \\
\hline 34 & McCartney (2007) & Working Paper & Framework Discussion \\
\hline 35 & Mokorosi and van der Zaag (2007) & Physics and Chemistry of the Earth & Unique framefwork with human rights focus \\
\hline 36 & Rossouw and Malan (2007) & Impact Assessment \& Project Appraisal & Framework discussion \\
\hline 37 & Cuong et al. (2006) & Report & Impoverishment risks and reconstruction model \\
\hline 38 & Jim and Yang (2006) & Environmental Management & Unique framework with focus on inundation and de-farming impacts \\
\hline 39 & Scudder (2006) & Monograph & Impoverishment risks and reconstruction model/relocation framework \\
\hline 40 & Tan and Yao (2006) & Population \& Environment & Unique framework \\
\hline 41 & Ersado (2005) & $\begin{array}{l}\text { Policy Research Working Paper Series from The } \\
\text { World Bank }\end{array}$ & Cost-benefit analysis \\
\hline 42 & Becker et al. (2004) & Impact Assessment \& Project Appraisal & Technical social analysis report/participatory interactive community forum \\
\hline 43 & Cernea (2004) & Keynote Address & Impoverishment risks and reconstruction model \\
\hline 44 & D'Souza (2004) & Political Geography & Unique framework with unit-of-analysis emphasis \\
\hline 45 & Morimoto and Hope (2004) & International Social Science Journal & Cost-benefit analysis \\
\hline 46 & Cernea (2003) & International Social Science Journal & Impoverishment risks and reconstruction model \\
\hline
\end{tabular}


Table 1 (continued)

\begin{tabular}{|c|c|c|c|}
\hline \# & Author(s) \& year of publication & Publication & Framework \\
\hline 47 & WCD (2000) & Report & World-commission-of dams-framework \\
\hline 48 & DFID (1999) & Report & Sustainability livelihoodframework \\
\hline 49 & Dwivedi (1999) & Development and Change & Impoverishment risks and reconstruction model (modified) \\
\hline 50 & Nakayama (1998) & $\begin{array}{l}\text { International Journal of Water Resources } \\
\text { Development }\end{array}$ & Environmental impact Assessment (modified) \\
\hline 51 & Dwivedi (1997) & Monograph & Impoverishment risks and reconstruction model (modified) \\
\hline 52 & Scudder (1997b) & Monograph & Relocation framework \\
\hline 53 & Pongsapich et al. (1994) & Journal of Business Administration & U. S. Corps of Engineersystem of tiers or levels framework \\
\hline 54 & Si (1993) & $\mathrm{PhD}$ thesis & Unique quality-of-life-framework \\
\hline 55 & Cernea (1990) & Discussion paper & Impoverishment risks and reconstruction model \\
\hline
\end{tabular}

\section{A.2. Depiction ofkeyreferenceframeworks}

\section{A.2.1. Relocation framework (Rf).}

The RF by Scudder and Colson (1982) is a four-stage-model describing "how the majority of resettlers can be expected to behave during a successful resettlement process" (Scudder, 2006):

- Stage 1 (Planning and Recruitment Stage) assumes that those to be resettled become increasingly concerned as their removal draws closer;

- Stage 2 (Adjustment and Coping) begins with the start of the actual resettlement, allegedly resulting in a drop in living standards and social stress;

- Stage 3 (Community Formation and Economic Development) is characterized by a reemergence of the resettled community. Growth may spur, the community develops again;

- Stage 4 (Handing Over and Incorporation) focuses on the second generation of those resettled. Herein, living standards continue to improve with the descendants of those resettled taking full ownerships of their lives and their community.

The framework is summarized in Fig. 3.

A.2.2. Impoverishment risks and reconstruction model (irr).

The impoverishment risks and reconstruction (IRR) model by Cernea (1997) describes seven different impoverishment risks through displacement.
These are:

- 1. Landlessness, i.e. farmers losing their land due to resettlement;

- 2. Joblessness, i.e. those resettled losing their job and unable to find a new one in the new resettlement location;

- 3. Homelessness, i.e. those resettled losing their home, possibly permanently, due to a relocation into a resettlement camp;

- 4. Marginalization, i.e. those resettled losing their standard of living due to new conditions that cannot be adjusted to in the new resettlement location;

- 5. Food insecurity, i.e. malnutrition due to a lack of food production capacity or food access in the resettlement location

- 6. Morbidity, i.e. severe illnesses, partly due to diseases spread by water borne agents due to reservoirs;

- 7. Social disarticulation, i.e. broken social networks due to the resettlement.

The framework is summarized in Fig. 4.

\section{A.2.3. Sustainable livelihoods framework (sl)}

The sustainable livelihoods framework (SL) depicts the main factors influencing people's livelihoods (their livelihoods assets), desirable livelihood outcomes as well as different livelihood strategies to reach these outcomes via the outlined assets. Different starting points for the SL framework are actually cited in the literature. For instance, McDonaldWilmsen and Webber (2010) argue in their discussion of different frameworks that Scoones (1998) would have developed the framework.

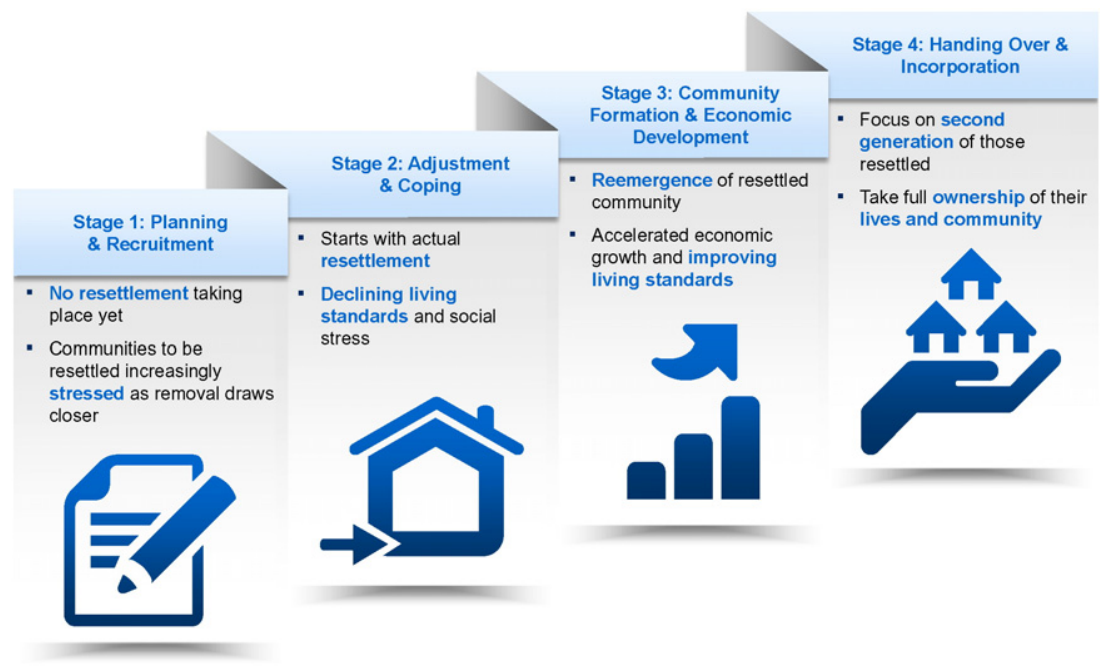

Fig. 3. Relocation Framework by Scudder \& Colson (1982). 


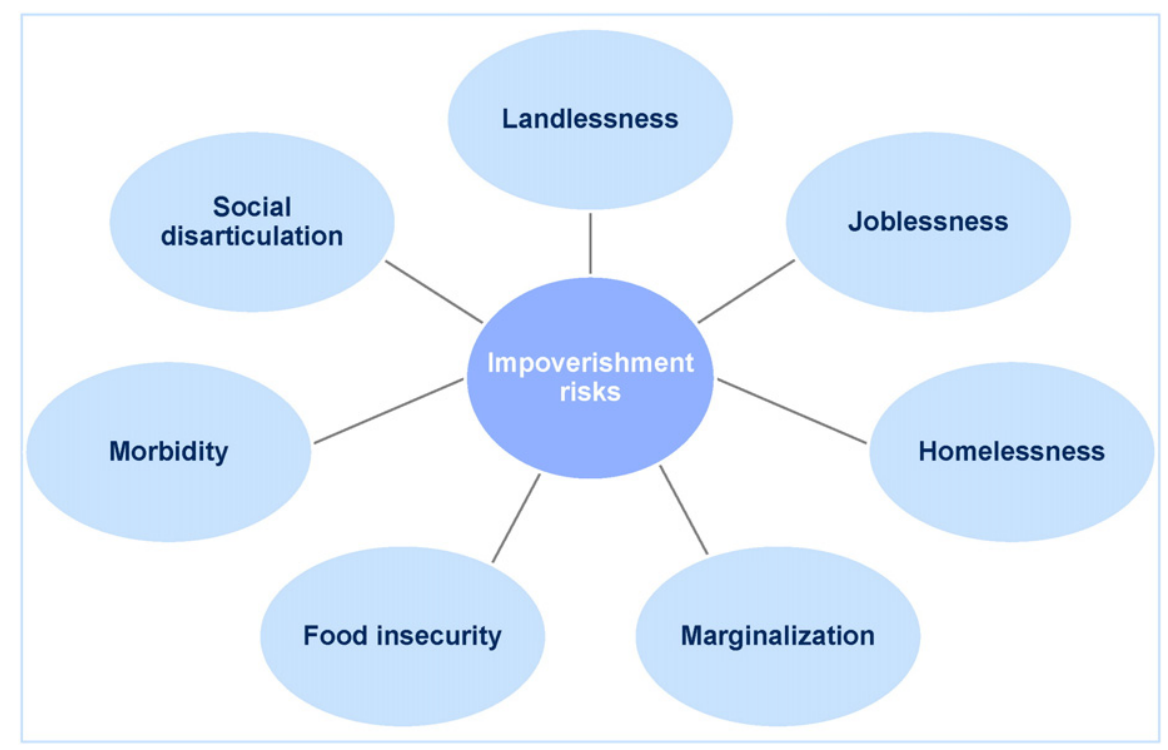

Fig. 4. Impoverishment Risks and Reconstruction (IRR) Model by Cernea (1990).

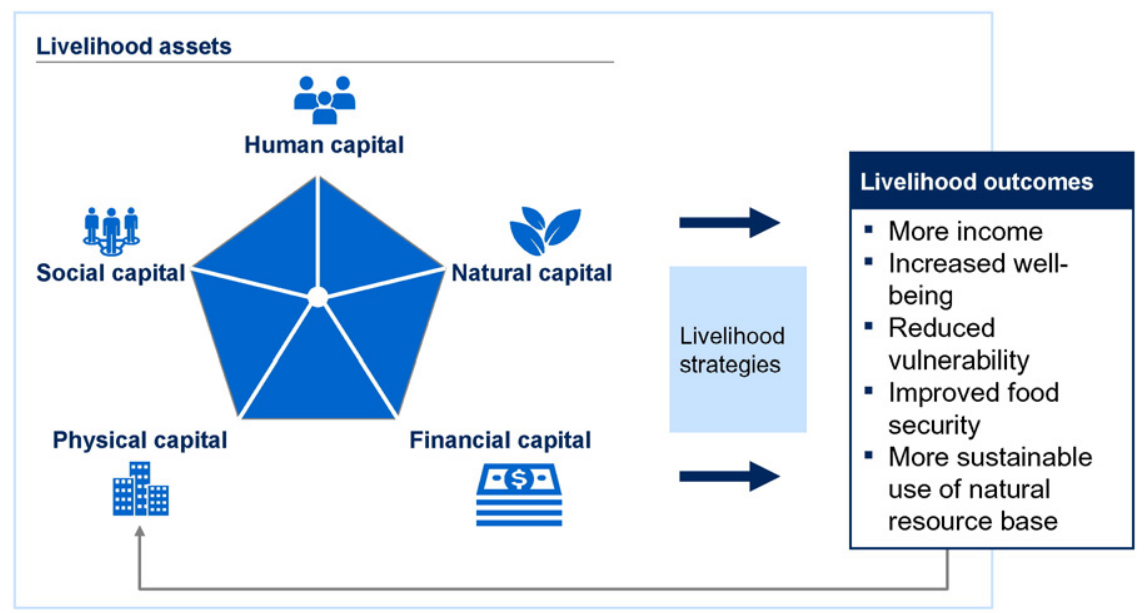

1 Simplified version not depicting vulnerability context as well as transforming structures and processes

Fig. 5. Sustainable Livelihoods Framework (SL) by DFID (1999).

However, Bui et al. (2013) as well as Bui and Schreinemachers (2011) who actually employ the framework in their empirical work refer to the version of the framework employed by DFID (1999). Thus, we are also referring to DFID version.

At its core is the asset pentagon containing five key components, namely:

- 1. Human capital, i.e. the skills, knowledge, ability to labor and good health;

- 2. Social capital, i.e. network and connectedness, membership in different groups as well as relationships of trust, reciprocity as well as exchanges;

- 3. Natural capital, i.e. natural resources stocks such as land, forests, water and air quality

- 4. Physical capital, i.e. basic infrastructure and producer goods such as transport, shelter and buildings, water supply and sanitation, energy and access to information

- 5. Financial capital, i.e. financial resources such as savings (stocks) as well earned income (flows).

Livelihood outcomes to reach via these assets are: (i) more income, (ii) increased well-being, (iii) reduced vulnerability, (iv) improved food security and (v) more sustainable use of the natural resource base. Livelihood strategies are not categorized within the framework. ${ }^{3}$.

The framework is summarized in Fig. 5.

\footnotetext{
${ }^{3}$ DFID (1999) defines livelihood strategies as "the range and combination of activities and choices that people undertake in order to achieve their livelihood goals".
} 
A.2.4. World-commission-of-dams-framework (wcd)

The WCD outlines seven strategic priorities for sustainable dam construction.

These are

- 1. Gaining public acceptance for the dam project, i.e. informing and involving stakeholders impacted by the construction of the dam;

- 2. Comprehensive options assessment, i.e. if there may be viable alternatives to large dam construction also reaching the same goals;

- 3. Addressing existing dams, i.e. taking into account the changing priorities for water use, land development and energy demands over time;

- 4. Sustaining rivers and livelihoods, i.e. protecting and restoring the ecosystem of the river basin as well as those livelihoods relying on it

- 5. Recognizing entitlements and sharing benefits, i.e. providing development provisions to those unfavorably affected by the dam construction
- 6. Ensuring compliance, i.e. adherence to internationally recognized guidelines of dam development

- 7. Sharing rivers for peace, development and security, i.e. fostering cooperation among countries via equitable and reasonable utilization of the water and energy resources in the river basin.

The framework is summarized in Fig. 6.

A.2.5. Integrative dam assessment model (Idam).

The IDAM is a multidisciplinary model on the social impact of dams spelling out 7 socio-economic components of impact, 7 geopolitical components of impact as well as 7 bio-physical components of impact. Different version of IDAM were published, e.g. Brown et al. (2009) and Tullos et al. (2010). We refer to the latest IDAM version identified in the literature. All components can be either positive or negative. Each component is also complemented by a set of

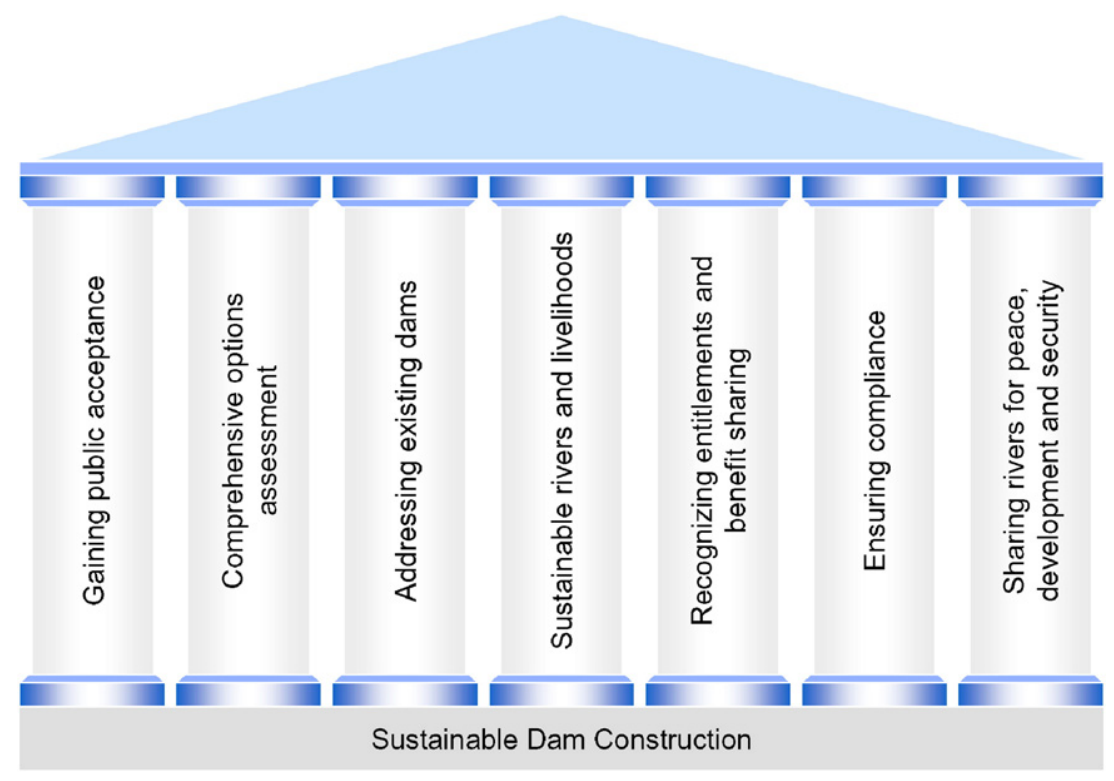

Fig. 6. World-Commission-of-Dams framework (WCD) by WCD (2000).

\begin{tabular}{|c|c|c|}
\hline Socioeconomic impacts & Geopolitical impacts & Biophysical impacts \\
\hline 1. Social cohesion & 1. Domestic shock & 1. Impact area \\
\hline $\begin{array}{l}\text { 2. Cultural knowledge and } \\
\text { behavior }\end{array}$ & $\begin{array}{l}\text { 2. International institutional } \\
\text { resilience }\end{array}$ & 2. Habitat diversity \\
\hline 3. Material culture & 3. Political complexity & 3. Carbon emission reduction \\
\hline 4. Infrastructure & 4. Legal framework & 4. Landscape stability \\
\hline 5. Income & $\begin{array}{l}\text { 5. Domestic governance } \\
\text { transparency }\end{array}$ & 5. Sediment modification \\
\hline 6. Wealth & 6. Domestic political stability & 6. Hydrologic modification \\
\hline 7. Macro impacts & $\begin{array}{l}\text { 7. International political } \\
\text { stability }\end{array}$ & 7. Water quality \\
\hline
\end{tabular}

Fig. 7. Integrative Dam Assessment Model (IDAM) by Kibler et al. (2012). 
quantitative indicators. In this paper, we have only focused on the 7 socio-economic components.

These are

- 1. Social cohesion, i.e. community trust, borrowing and lending networks as well as participation in village activities;

- 2. Cultural knowledge and behavior, i.e. the ethnic composition of the community, but also middle school enrollment rates;

- 3. Material culture, i.e. tombs and sites of cultural significance

- 4. Infrastructure, i.e. access to roads, electricity and potable water

- 5. Income, i.e. household income compared to watershed average

- 6. Wealth, i.e. housing values compared to watershed average

- 7. Macro-impacts, i.e. cost of resettlement and infrastructure or commercial value of hydropower produced.

The entire framework is summarized in Fig. 7.

\section{A.3. Interviews citedinpaper}

\section{Table 3}

Interview overview.

\begin{tabular}{clll}
\hline$\#$ & Interviewee & Organization & Code \\
\hline 1 & Leading scholar & American university & O20042015 \\
2 & Senior staff & Anti-dam-NGO & T22042015 \\
3 & Staff & International donor & T23042015a \\
4 & Staff & International donor & T23042015b \\
5 & Senior staff & International NGO & T30042015d \\
\hline
\end{tabular}

\section{References}

Alt, J.E., Shepsle, K.A. (Eds.), 1990. Perspectives on Positive Political Economy. Cambridge University Press, Melbourne.

Barrow, C.J., 2000. Social Impact Assessment - An Introduction. Arnold, London.

Beck, M.W., Claassen, A.H., Hundt, P.J., 2012. Environmental and livelihood impacts of dams: common lessons across development gradients that challenge sustainability. Int. J. River Basin Manag. 10 (1), 73-92. http://dx.doi.org/10.1080/ 15715124.2012.656133.

Becker, H.A., 2001. Social impact assessment. Eur. J. Oper. Res. 128 (2), 311-321. http://dx. doi.org/10.1016/S0377-2217(00)00074-6.

Becker, D.R., Harris, C.C., Nielsen, E.A., McLaughlin, W.J., 2004. A Comparison of a Technical and a Participatory Application of Social Impact Assessment. Retrieved from http:// www.tandfonline.com/doi/abs/10.3152/147154604781765932\#.VSUXGfmUeSo.

Bhatia, R., Cestti, R., Scatasta, M., Malik, R.P.S., 2008. Indirect Economic Impacts of Dams Case Studies from India. Egypt and Brazil, The World Bank Retrieved from http:// www-wds.worldbank.org/external/default/WDSContentServer/IW3P/IB/2010/02/ 03/000333037_20100203005948/Rendered/PDF/ 455240PUB0indi1010fficial0Use00nly1.pdf.

Brown, P.H., Magee, D., Xu, Y., 2008. Socioeconomic vulnerability in China's hydropower development. China Econ. Rev. 19 (4), 614-627. http://dx.doi.org/10.1016/j.chieco. 2008.06.002

Brown, P.H., Tullos, D., Tilt, B., Magee, D., Wolf, A.T., 2009. Modeling the costs and benefits of dam construction from a multidisciplinary perspective. J. Environ. Manag. 90 (Suppl. 3), S303-S311. http://dx.doi.org/10.1016/j.jenvman.2008.07.025.

Bui, T.M.H., Schreinemachers, P., 2011. Resettling farm households in Northwestern Vietnam: livelihood change and adaptation. Int. J. Water Resour. Dev. 1-17 http:// dx.doi.org/10.1080/07900627.2011.593116.

Bui, T.M.H., Schreinemachers, P., Berger, T., 2013. Hydropower development in Vietnam: involuntary resettlement and factors enabling rehabilitation. Land Use Policy 31, 536-544. http://dx.doi.org/10.1016/j.landusepol.2012.08.015.

Cernea, M., 1990. Poverty risks from population displacement in water resources development. Working Paper Retrieved from http://www.popline.org/node/ 379181.

Cernea, M. 1997. Impoverishment Risks, Risk Management, and Reconstruction: A Model of Population Displacement and Resettlement. Retrieved from http://communitymining. org/attachments/254_population_resettlement_IRR_MODEL_cernea.pdf.

Cernea, M.M., 2003. For a new economics of resettlement: a sociological critique of the compensation principle. Int. Soc. Sci. J. 55 (175), 37-45. http://dx.doi.org/10.1111/ $1468-2451.5501004$

Cernea, M., 2004. Social Impacts and Social Risks in Hydropower Programs: Preemptive Planning and Counter-risk Measures. Retrieved from http://www.un.org/esa/ sustdev/sdissues/energy/op/hydro_cernea_social impacts_backgroundpaper.pdf.

Chen, H., 2013. Sustainable Development in China's Decision Making on Large Dams: A case study of the Nu River Basin. Retrieved from http://uu.diva-portal.org/smash/ get/diva2:646252/FULLTEXT01.pdf.
Cleetus, R., Clemmer, S., Davis, E., Deyette, J., Downing, J., Frenkel, S., 2012. Ripe for Retirement - The Case for Closing America's Costliest Coal Plants. Retrieved from http://www.ucsusa.org/sites/default/files/legacy/assets/documents/clean_ energy/Ripe-for-Retirement-Full-Report.pdf.

Coakes, S., Sadler, A., 2011. Utilizing a sustainable livelihoods approach to inform social impact assessment practice. In: Vanclay, F., Esteves, A.M. (Eds.), New Directions in Social Impact Assessment. Edward Elgar Publishing Limited, Cheltenham.

Cuong, N.M., Nga, D.T.V., Sa, L.K., Phuong, N.T., Van, T.H., Anh, N.H., ... Truong, N.D., 2006. A Work in Progress: Study on the Impacts of Vietnam's Son La Hydropower Project. Retrieved from http://www.internationalrivers.org/files/attached-files/ sonla2006.pdf.

DFID, 1999. Sustainable Livelihoods Guidance Sheets. Retrieved from http://www.eldis. org/vfile/upload/1/document/0901/section2.pdf.

Dobbs, R., Pohl, H., Lin, D.-Y., Mischke, J., Garemo, N., Hexter, J., ... Nanavatty, R., 2013. Infrastructure Productivity: How to Save \$1 Trillion a Year. Retrieved from http:// www.mckinsey.com/insights/engineering_construction/infrastructure_productivity.

Downing, T.E., Garcia-Downing, C., 2009. Routine and dissonant cultures: a theory about the psycho-socio-cultural disruptions of involuntary displacement and ways to mitigate them without inflicting even more damage. Development and Dispossession: The Anthropology of Displacement and Resettlement Retrieved from http:// allthingsaz.com/wp-content/uploads/2012/01/Routine-and-Dissonant-Culture-TDowning-and-C-GarciaDowning1.pdf.

D'Souza, R., 2004. The democracy-development tension in dam projects. Polit. Geogr. 23 (6), 701-730. http://dx.doi.org/10.1016/j.polgeo.2004.03.003.

Duflo, E., Pande, R., 2007. Dams. Q. J. Econ. 122 (2), 601-646. http://dx.doi.org/10.1162/ qjec.122.2.601.

Dwivedi, R., 1997. Why Some People Resist and Others Do Not : Local Perceptions and Actions Over Displacement Risks on the Sardar Sarovar. Institute of Social Studies, The Hague.

Dwivedi, R., 1999. Displacement, risks and Resistance: local perceptions and actions in the Sardar Sarovar. Dev. Chang. 30 (1), 43-78. http://dx.doi.org/10.1111/ $1467-7660.00107$

Égré, D., Senécal, P., 2003. Social impact assessments of large dams throughout the world lessons learned over two decades. Impact Assess. Proj. Apprais. 21 (3), 215-224. http://dx.doi.org/10.3152/147154603781766310.

Erlanger, T.E., Sayasone, S., Krieger, G.R., Kaul, S., Sananikhom, P., Tanner, M., ... Utzinger, J., 2008. Baseline health situation of communities affected by the Nam Theun 2 hydroelectric project in central Lao PDR and indicators for monitoring. Int. J. Environ. Health Res. 18 (3), 223-242. http://dx.doi.org/10.1080/09603120701757815.

Ersado, L., 2005. Small-scale irrigation dams, agricultural production, and health - theory and evidence from Ethiopia. The World Bank Retrieved from http://econpapers. repec.org/RePEc:wbk:wbrwps:3494.

Esteves, A.M., Franks, D., Vanclay, F., 2012. Social impact assessment: the state of the art. Impact Assess. Proj. Apprais. 30 (1), 34-42. http://dx.doi.org/10.1080/14615517.2012. 660356

Greathouse, E.A., Pringle, C.M., McDowell, W.H., Holmquist, J.G., 2006. Indirect upstream effects of dams: consequences of migratory consumer extirpation in Puerto Rico. Ecol. Appl.: Publ. Ecol. Soc. Am. 16 (1), 339-352 Retrieved from. http://www.ncbi. nlm.nih.gov/pubmed/16705984.

Harvey, B., 2011. SIA from a resource developer's perspective. In: Vanclay, F., Esteves, A.M. (Eds.), New Directions in Social Impact Assessment. Edward Elgar Publishing Limited, Cheltenham.

Hennig, T., Wang, W., Feng, Y., Ou, X., He, D., 2013. Review of Yunnan's hydropower development. Comparing small and large hydropower projects regarding their environmental implications and socio-economic consequences. Renew. Sust. Energ. Rev. 27 585-595.

Howitt, R., 2011. Theoretical foundations. In: Vanclay, F., Esteves, A.M. (Eds.), New Directions in Social Impact Assessment. Edward Elgar Publishing Limited, Cheltenham.

IAIA, 2016. Iaia Vision \& Mission. Retrieved from http://www.iaia.org/about.php.

IHA, 2010. Hydropower Sustainability Assessment Protocol. International Hydropower Association. Retrieved from http://www.hydrosustainability.org/IHAHydro4Life/ media/PDFs/Protocol/hydropower-sustainability-assessment-protocol_web.pdf.

International Association for Impact Assessment (IAIA), 2014. Social impact assessent Retrieved from http://www.iaia.org/uploads/pdf/KeyCitations_SIA.pdf.

International Hydropower Association (IHA), 2015. 39 GW of hydropower added in 2014 Retrieved from http://www.hydropower.org/blog/39-gw-of-hydropower-added-in2014.

Jim, C.Y., Yang, F.Y., 2006. Local responses to inundation and de-farming in the reservoir region of the three gorges project (China). Environ. Manag. 38 (4), 618-637. http:// dx.doi.org/10.1007/s00267-005-0253-8.

Jordan, T., Lent, A., McKay, G., Mische, A., 2011. Soc. Mov. Stud. Retrieved from http:// www.tandf.co.uk/journals/titles/CSMS_opening.asp.

Juslén, J., 1995. Social impact assessment: a look at Finnish experiences. Proj. Apprais. 10 (3), 163-170. http://dx.doi.org/10.1080/02688867.1995.9726990.

Kibler, K., Tullos, D., Tilt, B., Wolf, A., Magee, D., Foster-Moore, E., Gassert, F., 2012. Integrative Dam Assessment Model (IDAM) Documentation: Users Guide to the IDAM Methodology and a Case Study from Southwestern China. Oregon State University Corvallis, Oregon Retrieved from http://www.transboundarywaters.orst.edu/ research/IDAM/IDAM Manual 12.pdf.

Kittinger, J.N., Coontz, K.M., Yuan, Z., Han, D., Zhao, X., Wilcox, B.A., 2009. Toward holistic evaluation and assessment: linking ecosystems and human well-being for the three gorges dam. EcoHealth 6 (4), 601-613. http://dx.doi.org/10.1007/s10393-010-0285-2

Kurniati, E., Sutanhaji, A.T., Anggraini, O.A., 2013. Land Acquisition and Resettlement Action Plan (LARAP) of dam project using Analytical Hierarchical Process (AHP): A case study in Mujur Dam, Lombok Tengah District-West Nusa Tenggara, Indonesia. Procedia Environ. Sci. 17, 418-423. http://dx.doi.org/10.1016/j.proenv.2013.02.055. 
Larson, S., 2007. Index-based tool for preliminary ranking of social and environmental impacts of hydropower and storage reservoirs. Energy 32 (6), 943-947. http://dx.doi. org/10.1016/j.energy.2006.09.007.

Lerer, L.B., Scudder, T., 1999. Health impacts of large dams. Environ. Impact Assess. Rev. 19 (2), 113-123 10.1016/S0195-9255(98)00041-9.

Lewellen, T.C., 2003. Political Anthropology - an Introduction. Praeger.

Luwa, K.J., 2007. Power and Development: Controversies over the Bujagali Hydropower Project Along the Nile River in Uganda. Retrieved from http://liu.diva-portal.org/ smash/get/diva2:37557/FULLTEXT01.pdf.

Matthews, N. (2013). PhD thesis (embargoed)

McCartney, M.P., 2007. Decision Support Systems for Large Dam Planning and Operation in Africa. Retrieved from http://www.iwmi.cgiar.org/Publications/Working_Papers/ working/WOR119.pdf.

McDonald-Wilmsen, B., Webber, M., 2010. Dams and displacement: raising the standards and broadening the research agenda. Water Altern. 3 (2), 142-161 Retrieved from http://www.water-alternatives.org/index.php/volume3/v3issue2/87-a3-2-10/file.

McNally, A., Magee, D., Wolf, A.T., 2009. Hydropower and sustainability: Resilience and vulnerability in China's powersheds. J. Environ. Manag. 90, S286-S293. http://dx. doi.org/10.1016/j.jenvman.2008.07.029.

Miles, M.B., Huberman, A.M., 1994. An Expanded Sourcebook: Qualitative Data Analysis. 2nd Editio. SAGE Publications.

Mirumachi, N., Torriti, J., 2012. The use of public participation and economic appraisal for public involvement in large-scale hydropower projects: case study of the Nam Theun 2 Hydropower Project. Energy Policy 47, 125-132. http://dx.doi.org/10.1016/j.enpol. 2012.04.034.

Mokorosi, P.S., van der Zaag, P., 2007. Can local people also gain from benefit sharing in water resources development? Experiences from dam development in the OrangeSenqu River Basin. Phys. Chem. Earth A/B/C 32 (15-18), 1322-1329. http://dx.doi org/10.1016/j.pce.2007.07.028.

Morimoto, R., Hope, C., 2004. A CBA model of a hydro project in Sri Lanka. Int. J. Glob. Energy Issues 21 (1-2), 47-68 Retrieved from http://inderscience.metapress.com/ content/mlbduuecu5wx71m6

Nakayama, M., 1998. Post-project review of environmental impact assessment for Saguling Dam for involuntary resettlement. Int. J. Water Resour. Dev. 14 (2), 217-229. http://dx.doi.org/10.1080/07900629849411.

Oliver-Smith, A., 2009. Introduction. Development-forced displacement and resettlement: a global human rights crisis. Development and Dispossession: The Anthropology of Displacement and Resettlement. School for Advanced Research Press, Santa Fe.

Plummer, J., 2013. Assessing the Effects of Pre-construction Delay in Hydropower Projects. Department of Engineering, Centre for Sustainable Development, University of Cambridge, Cambridge.

Plummer Braeckman, J., Guthrie, P., 2015. Loss of value: effects of delay on hydropowe stakeholders. Proceedings of the Institution of Civil Engineers - Engineering Sustainability, jensu.15.00027 http://dx.doi.org/10.1680/jensu.15.00027.

Pongsapich, A., Phutharaporn, K., Lapthananon, P., 1994. Social environmental impact assessment and ethnic minorities: state vs. local interest in Khao Laem Dam construction. J. Bus. Adm. 22, 293 Retrieved from https://www.questia.com/library/journal/ 1G1-18515622/social-environmental-impact-assessment-and-ethnic.

Price, S., 2009. Prologue: victims or partners? The social perspective in development-induced displacement and resettlement. Asia Pac. J. Anthropol. 10 (4), 266-282. http://dx.doi.org/10.1080/14442210903305821.

Qi, H., Altinakar, M.S., 2012. GIS-based decision support system for dam break flood management under uncertainty with two-dimensional numerical simulations. J. Water Resour. Plan. Manag. 138 (4), 334-341. http://dx.doi.org/10.1061/(ASCE)WR.1943-5452. 0000192.

Richter, B.D. Postel, S., Revenga, C., Scudder, T., Lehner, B., Churchill, A., Chow, M., 2010. Lost in development's shadow: the downstream human consequences of dams. Water Altern. 3 (2), 14-42 Retrieved from http://www.water-alternatives.org/ index.php/volume3/v3issue2/80-a3-2-3/file.

Rojanamon, P., Chaisomphob, T., Bureekul, T., 2009. Application of geographical in formation system to site selection of small run-of-river hydropower project by considering engineering/economic/environmental criteria and social impact. Renew. Sust. Energ. Rev. 13 (9), 2336-2348. http://dx.doi.org/10.1016/j.rser. 2009.07.003

Rossouw, N., Malan, S., 2007. The importance of theory in shaping social impact monitoring: lessons from the Berg River Dam, South Africa. Impact Assess. Proj. Apprais. 25 (4), 291-299. http://dx.doi.org/10.3152/146155107X246305.

Sayatham, M., Suhardiman, D., 2015. Hydropower resettlement and livelihood adaptation: the Nam Mang 3 project in Laos. Water Resourc. Rural Dev. 5, 17-30. http:// dx.doi.org/10.1016/j.wrr.2015.01.001.

Schneider, H., 2013. World Bank rethinks stance on large-scale hydropower projects. The Guardian Retrieved from http://www.theguardian.com/environment/2013/may/14/ world-bank-hydropower-dam-rethink.

Scoones, I., 1998. Sustainable rural livelihoods - a framework for analysis. Retrieved from https://www.staff.ncl.ac.uk/david.harvey/AEF806/Sconnes1998.pdf.

Scudder, T., 1997a. Social Impacts. In: Biswas, A.K. (Ed.), Water Resources: Environmental Planning, Management and Development. McGraw-Hill Professional.

Scudder, T., 1997b. Social Impacts of Large Dams. Large Dams: Learning from the Past. IUCN

Scudder, T., 2005. OECD environmental and social policies for hydro dams. Retrieved from http://www.oecd.org/tad/xcred/35114770.pdf.

Scudder, T., 2006. The Future of Large Dams: Dealing with Social, Environmental Routledge, Institutional and Political Costs.

Scudder, T., 2011. Development-induced community resettlement. In: Vanclay, F. Esteves, A.M. (Eds.), New Directions in Social Impact Assessment. Edward Elgar Publishing Limited, Cheltenham.
Scudder, T., 2012. Resettlement outcomes of large dams. In: Tortajada, C., Altinbilek, D., Biswas, A.K. (Eds.), Impacts of Large Dams: A Global Assessment. Springer, Berlin Heidelberg.

Scudder, T., Colson, E., 1982. From welfare to development: a conceptual framework for the analysis of dislocated people. In: Hansen, A., Oliver-Smith, A. (Eds.), Involuntary Migration and Resettlement: The Problems and Responses of Dislocated People. Westview Press, Boulder, United States.

Shields, M.A., 1974. Social impact studies: an expository analysis. Environ. Behav. Retrieved from http://eric.ed.gov/?id=EJ128316.

Si, Z., 1993. A Theoretical Framework for Social Impact Analysis with Special Reference to Population Relocation at the Mactaquac Dam Project on the Saint John River. Dalhousie University Retrieved from http://dalspace.library.dal.ca//handle/10222/55366.

Singer, J., Watanabe, T., 2014. Reducing reservoir impacts and improving outcomes for dam-forced resettlement: experiences in central Vietnam. Lakes Reserv. Res. Manag. 19 (3), 225-235. http://dx.doi.org/10.1111/lre.12072.

Slootweg, R., Vanclay, F., van Schooten, M., 2001. Function evaluation as a framework for the integration of social and environmental impact assessment. Impact Assess. Proj. Apprais. 19 (1), 19-28. http://dx.doi.org/10.3152/147154601781767186.

SRP, 2015. Theodore Roosevelt Dam. Retrieved from http://www.srpnet.com/water/ dams/roosevelt.aspx.

Strobl, E., Blanc, E., 2013. Is Small Better ? A Comparison of the Effect of Large and Small Dams on Cropland Productivity in South Africa. pp. 1-53 Retrieved from http:// documents.worldbank.org/curated/en/2013/08/18104538/small-better-comparisoneffect-large-small-dams-cropland-productivity-south-africa.

Strobl, E., Strobl, R.O., 2011. The distributional impact of large dams: evidence from cropland productivity in Africa. J. Dev. Econ. 96 (2), 432-450. http://dx.doi.org/10.1016/j. jdeveco.2010.08.005.

Tajziehchi, S., Monavari, S.M., Karbassi, A., 2012. An effective participatory-based method for dam social impact assessment. Pol. J. Environ. Stud. 21 (6), 6(21) Retrieved from https://www.infona.pl//resource/bwmeta1.element.agro-e003b236-5c35-4cdaa334-3fc1108b00df

Tajziehchi, S., Monavari, S.M., Karbassi, A.R., Shariat, S.M., Khorasani, N., Narimisa, P., 2014. A critical look at social impact evaluation of dam construction by Revised SIMPACTS Software - a case study of Alborz Dam in Northern Iran. Int. J. Environ. Res. 8 (2), 329-334 Retrieved from http://www.ijer.ir/article_723_8.html.

Takesada, N., 2009. Japanese experience of involuntary resettlement: long-term consequences of resettlement for the construction of the Ikawa Dam. Int. J. Water Resourc. Dev. 25 (3), 419-430. http://dx.doi.org/10.1080/07900620902965459.

Tan, Y., Yao, F., 2006. Three gorges project: effects of resettlement on the environment in the reservoir area and countermeasures. Popul. Environ. 27 (4), 351-371. http://dx. doi.org/10.1007/s11111-006-0027-0.

Platts, 2015. The Top 100 - Part I - The World's Largest Power Plants. Retrieved from http://www.industcards.com/top-100-pt-1.htm.

Tilt, B., Braun, Y., He, D., 2009. Social impacts of large dam projects: a comparison of international case studies and implications for best practice. J. Environ. Manag. 90 (Suppl. 3), S249-S257. http://dx.doi.org/10.1016/j.jenvman.2008.07.030.

Tullos, D., Brown, P.H., Kibler, K., Magee, D., Tilt, B., Wolf, A.T., 2010. Perspectives on the Salience and Magnitude of Dam Impacts for Hydro Development Scenarios in China, 3 Water Alternatives. pp. 71-90.

Tullos, D. D., Foster-Moore, E., Magee, D., Tilt, B., Wolf, A. T., Schmitt, E., ... Kibler, K. (2013). Biophysical, socioeconomic, and geopolitical vulnerabilities to hydropower development on the Nu River, China. Ecol. Soc., 18(3). 10.5751/ES-05465-180316, ((art16)).

Vanclay, F., 2002. Conceptualising social impacts. Environ. Impact Assess. Rev. 22 (3), 183-211. http://dx doi.org/10.1016/S0195-9255(01)00105-6.

Vanclay, F., 2004. The triple bottom line and impact assessment: how do TBL, EIA, SIA, SEA and EMS relate to each other? J. Environ. Assess. Policy Manag. 06 (03), 265-288. http://dx.doi.org/10.1142/S1464333204001729.

Vanclay, F., 2015. Changes in the impact assessment family 2003-2014: implications for considering achievements, gaps and future directions. J. Environ. Assess. Policy Manag. 17 (01), 1550003. http://dx.doi.org/10.1142/S1464333215500039.

Vanclay, F., Esteves, A.M., 2011. Current issues and trends in social impact assessment. In: Vanclay, F., Esteves, A.M. (Eds.), New Directions in Social Impact Assessment. Edward Elgar Publishing Limited, Cheltenham.

Vanclay, F, Esteves, A.M. Aucamp, I. Franks, D.M. 2015. Social impact assessment: guidance for assessing and managing the social impacts of projects. Retrieved from http://www.iaia.org/uploads/pdf/SIA_Guidance_Document_IAIA.pdf.

Wang, P., Lassoie, J.P., Dong, S., Morreale, S.J., 2013. A framework for social impact analysis of large dams: a case study of cascading dams on the Upper-Mekong River, China. J. Environ. Manag. 117, 131-140. http://dx.doi.org/10.1016/j.jenvman.2012.12.045.

WCD, 2000. Dams and Development - A New Framework for Decision-Making. World Commission on Dams. Retrieved from http://www.internationalrivers.org/files/ attached-files/world_commission_on_dams_final_report.pdf.

Wilmsen, B., Webber, M., Duan, Y., 2011a. Involuntary rural resettlement: resources, strategies, and outcomes at the Three Gorges Dam, China. J. Environ. Dev. 20 (4), 355-380. http://dx.doi.org/10.1177/1070496511426478.

Wilmsen, B., Webber, M., Yuefang, D., 2011b. Development for whom? Rural to urban resettlement at the Three Gorges Dam, China. Asian Stud. Rev. 35 (1), 21-42. http://dx. doi.org/10.1080/10357823.2011.552707.

World Energy Council, 2015. Energy resources - hydropower. Retrieved from https:// www.worldenergy.org/data/resources/resource/hydropower/.

Zarfl, C., Lumsdon, A.E., Berlekamp, J., Tydecks, L., Tockner, K., 2014. A global boom in hydropower dam construction. Aquat. Sci. 77 (1), 161-170. http://dx.doi.org/10.1007/ s00027-014-0377-0.

Zhang, Y., He, D., Lu, Y., Feng, Y., Reznick, J., 2013. The influence of large dams building on resettlement in the Upper Mekong River. J. Geogr. Sci. 23 (5), 947-957. http://dx.doi. org/10.1007/s11442-013-1054-2. 


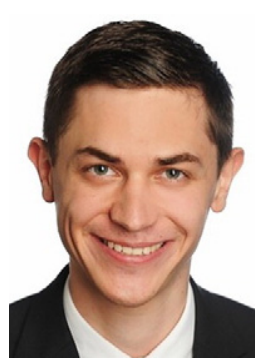

Julian Kirchherr is a doctoral researcher at the School of Geography and the Environment, University of Oxford, investigating various socio-economic impacts of dams in Southeast Asia. He was with McKinsey \& Company before that, advising governments in Europe, Asia and the Middle East.

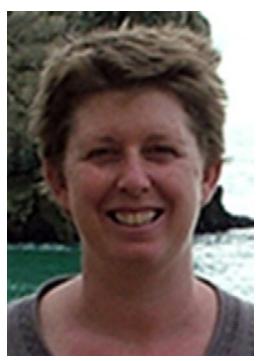

Katrina J. Charles is a lecturer at the School of Geography and the Environment, University of Oxford. Her research investigates the relationship between water security, health and poverty in Asia and Africa. 